\title{
IFRS Adoption, Reporting Incentives, and Financial Reporting Quality in Private Firms
}

\author{
Moritz Bassemir \\ Goethe University Frankfurt \\ Zoltán Novotny-Farkas \\ Lancaster University Management School
}

Forthcoming in Journal of Business Finance \& Accounting

\begin{abstract}
This study examines financial reporting quality (FRQ) effects around voluntary International Financial Reporting Standards (IFRS) adoptions by German private firms across two important dimensions, earnings quality and disclosure practices. To capture differences in the motivations for IFRS adoptions, we identify four different types of IFRS adopting firms based on a comprehensive set of firm characteristics. We observe earnings quality improvements around IFRS adoptions primarily for one type of firms, which are young, fast growing and seeking access to public equity markets. Using a matched sample of private German GAAP and IFRS reporting firms, we find some evidence suggesting that IFRS also contribute to higher earnings quality. Recognizing that our earnings quality metrics are only incomplete measures of FRQ, we also compare the disclosure practices of IFRS and German GAAP firms. We find that all IFRS firm types disclose significantly more information in their financial reports and show a higher propensity to publish their financial reports voluntarily on the corporate website. Our findings indicate that failure to identify earnings quality changes around IFRS adoption cannot be automatically interpreted as IFRS adoption having no effect on the FRQ of (private) firms. Collectively, our results suggest that both incentives and accounting standards shape private firms' FRQ.
\end{abstract}

\section{JEL classification: M4}

Keywords: International Financial Reporting Standards (IFRS), Reporting Incentives, Financial Reporting Quality, Private Firms

\footnotetext{
We thank Günther Gebhardt, Igor Goncharov, Luzi Hail, Christian Leuz, Patricia Ruffing, Michael Scholz, Cathy Schrand, Anne Wyatt (Associate Editor), an anonymous referee, conference participants at the JBFA Capital Markets conference and workshop participants at the Wharton School, Humboldt University of Berlin, Goethe University Frankfurt, Tilburg University, and Maastricht University for helpful comments. We also appreciate comments on earlier versions of this paper at the INTACCT meetings in Varna, Ljubljana, and at the EAA Annual Congress in Rome. We thank for the financial support of the Deutsche Forschungsgemeinschaft (GE 600/5-1). Zoltán NovotnyFarkas gratefully acknowledges the financial support of the European Commission Research Training Network INTACCT (Contract MRTN-CT-2006-035850). Part of this research was conducted while Zoltán Novotny-Farkas was visiting the Wharton School.
} 


\section{Introduction}

In this paper we investigate financial reporting quality (FRQ) effects around the voluntary adoption of International Financial Reporting Standards (IFRS) by German private firms across two important dimensions, earnings quality and disclosure practices. ${ }^{1}$ Our paper is motivated by two streams of the accounting literature. First, following the worldwide introduction of IFRS substantial research has focused on the financial reporting effects of IFRS adoptions in publicly listed firms. The collective empirical evidence suggests that while high quality accounting standards contribute to earnings quality improvements around voluntary IFRS adoptions (e.g., Barth et al. 2008), such improvements are confined to a subset of firms with strong reporting incentives (e.g., Daske et al. 2013; Christensen et al. 2015). Second, a growing literature examining FRQ in the private firm setting shows that variation in financing, ownership and organizational structure leads to heterogeneity in the earnings quality of private firms (Ball and Shivakumar 2008; Hope et al. 2013; Haw et al. 2014; Hope et al. 2017). However, neither of the two streams speaks to the impact of voluntary IFRS adoptions on the FRQ of private firms and how FRQ varies with firms' motivations to switch accounting standards.

This research question is particularly interesting since private firms are typically characterized by concentrated ownership, insider orientation and low demand for high FRQ (Ball and Shivakumar 2005; Burgstahler et al. 2006). Yet, in recent years, an increasing number of private firms have voluntarily adopted IFRS. Empirical studies show that the decision to adopt is associated with external financing needs (as indicated by Initial Public Offerings (IPOs), public bond issuances, high sales growth), certain governance features such as private

1 Throughout the paper we use the term financial reporting quality (FRQ) as an umbrella term subsuming the terms earnings (or accounting) quality and disclosure quality, both of which capture related, but different FRQ aspects. "Quality" refers to the extent to which accounting information reflects the underlying economic situation of the firm and is related to the broader concept of "transparency" (Ball et al. 2003). 
equity (PE) ownership and incorporated status, and internationalization (Francis et al. 2008; Bassemir 2017). However, it is not clear which of the numerous motives to adopt IFRS represent a commitment to higher FRQ and whether IFRS per se contribute to changes in FRQ of private firms in the first place.

Based on prior evidence, we expect FRQ effects to be jointly determined by the quality of IFRS and private firms' reporting incentives. Germany offers an ideal setting to investigate our research question. German GAAP or the German Commercial Code (Handelsgesetzbuch; hereafter, HGB) is insider-oriented and dominated by the prudence principle with limited recognition of assets and the discretionary use of provisions resulting in pervasive earnings management (Leuz and Wüstemann 2004; Hung and Subramanyam 2007). ${ }^{2}$ In contrast, IFRS are perceived as higher quality accounting standards because IFRS limit managerial discretion, promote more conditionally conservative accounting and require more disclosure (Leuz 2003; André et al. 2015). Hence, to the extent that accounting standards matter, financial statement effects are likely to be strong in this setting. However, given the lack of enforcement in the private firm setting and the flexibility embedded in IFRS (e.g., Kvaal and Nobes 2010), firmlevel reporting incentives are potentially important in shaping FRQ effects around IFRS adoptions (Daske et al. 2013; Christensen et al. 2015).

Incentives for high FRQ arise primarily for two reasons (Beyer et al. 2010). First, when (potential) external capital providers want to evaluate the profit potential of the firm they need high FRQ to resolve information asymmetries with managers (valuation role). Second, when capital providers (e.g., owners, suppliers) cannot directly observe the actions of managers, they

2 We use the term "German GAAP" broadly to refer to all legal rules, principles and standards that German companies have to apply in the preparation of their financial statements. "HGB" refers to specific legal rules as codified in the German Commercial Code. 
rely on financial reporting as a monitoring tool to alleviate agency problems (stewardship role). Yet, insiders to the firm often prefer opacity to protect their private benefits of control or informational rents (of relationship lenders) (Rajan and Zingales 1998). Therefore, we posit that in the private firm setting incentives for higher FRQ around IFRS adoptions will depend on the relative importance of valuation and stewardship problems and the insider-outsider conflict. To capture variation in the incentives for high FRQ, we identify different types of IFRS adopters.

For our empirical analysis, we identify 273 German private firms that voluntarily adopted full IFRS in their consolidated financial statements between 1998 and 2010. We start our analysis by identifying the motivations of IFRS firms to switch accounting standards. Specifically, we classify private firms into different types of IFRS adopters using factor and cluster analysis based on a comprehensive set of firm characteristics and economic events that prior studies found to coincide with the accounting switch (e.g., Bassemir 2017). Since many of these observable firm characteristics and economic events are highly interdependent, we intentionally refrain from partitioning firms based on single characteristics and from drawing conclusions based on dichotomous classifications. Instead, we use factor analysis to identify latent factors based on the common variance among firm characteristics, which we interpret as the primary motivations for IFRS adoptions. Then, we perform cluster analysis on the factor scores to group firms into four types of firms that differ in terms of their primary motivations for IFRS adoption which are access to public equity markets (which we label EQUITY firms), access to public debt markets (DEBT firms), ownership and reorganization by private equity firms (FINCON-PE firms), and internationalization (REPUTATION firms). We argue that the valuation and stewardship problems are highest in EQUITY firms, because of the entrance of outside investors and the largest separation of ownership and control, and lowest in REPUTATION firms that do not tap public capital markets. While DEBT (FINCON-PE) firms 
face higher (intermediate) valuation problems, stewardship problems are relatively low because of the tight grip of family (private equity) controlling owners. Taken together, we expect incentives for high FRQ to be highest in EQUITY and lowest in REPUTATION firms.

We focus on two dimensions of private firm FRQ, earnings quality and disclosure. We measure earnings quality using two manifestations of earnings management, income smoothing and managing towards positive earnings, and one timely loss recognition metric (e.g., Barth et al. 2008; Ahmed et al. 2013; Christensen et al. 2015). We measure disclosure using the length of financial reports and the length of notes sections therein, the level of disclosure detail related to goodwill and deferred taxes, two balance sheet items that are particularly different between IFRS and German GAAP, and firms' propensity to voluntarily publish financial reports on their websites. Since IFRS are outsider oriented, we take the perspective of outsiders and consider less earnings management, more timely loss recognition and more disclosure as high FRQ.

For our earnings quality analysis, we perform two sets of empirical tests. The first set of tests examines heterogeneity in earnings quality across different types of IFRS adopting firms. First, we make a cross-sectional comparison of the earnings quality of different types of IFRS adopters in the post-adoption period with the average earnings quality of a pooled (unmatched) benchmark sample of private German GAAP firms over the sample period. We find that EQUITY firms exhibit significantly less income smoothing and more timely loss recognition in the post-adoption period than the average German GAAP firm and other types of IFRS adopters. In contrast, DEBT firms generally smooth income more than German GAAP firms suggesting that despite their capital market orientation insiders create incentives for managers to conceal firm performance. FINCON-PE and REPUTATION firms exhibit a similar level of income smoothing and timely loss recognition as the average German GAAP firm. 
Interestingly, all IFRS firm types generally show a lower incidence of small profits than German GAAP firms.

Second, for a subsample of firms where pre- and post-adoption data are available, we examine whether the different IFRS-adoption types experience a within-firm improvement of earnings quality. Again, we find that EQUITY firms experience the largest improvement in earnings quality around IFRS adoption consistent with these firms facing the greatest valuation and stewardship problems. Furthermore, neither DEBT nor FINCON-PE firms evidence improvements in earnings quality around IFRS adoption. Interestingly, REPUTATION firms experience an improvement in their earnings quality in the post-adoption period.

To isolate the incremental effect of IFRS, our second set of tests repeats the two previous analyses using a propensity score-matched sample of private IFRS and German GAAP firms. While the matched sample tests are the most rigorous in terms of empirical validity, they come at the cost of a significantly reduced sample size, which prevents us from running these tests separately for each type of firms. We find evidence that IFRS firms exhibit higher earnings quality (improvements) after (around) the adoption of IFRS than their German GAAP counterparts indicating an incremental effect of accounting standards. Finally, a differencesin-differences analysis provides weak statistical support for IFRS firms improving their earnings quality more than German GAAP firms.

Our earnings quality analyses have several caveats. First, given that we rely on balance sheet accruals, important economic events like IPOs can mechanically lead to large changes in the earnings quality proxies (Hribar and Collins 2002). We mitigate this concern by excluding the first IFRS year, but cannot entirely eliminate it. Second and related, the empirical proxies employed in our analyses contain substantial measurement error that increases the possibility of Type 1 and Type 2 errors. Finally, earnings quality proxies are only incomplete measures of overall FRQ. 
In order to capture other aspects of FRQ where IFRS adoption effects are presumably easier to detect, we also examine the disclosure practices of private firms. We find that financial reports prepared by IFRS firms and in particular their notes sections contain significantly more pages than those of matched German GAAP firms. Since page numbers is a quantitative measure potentially influenced by boilerplate-type disclosure, we further construct a disclosure content score designed to capture the level of disclosure detail regarding deferred taxes and goodwill. Our results show that IFRS financial reports offer significantly more detailed information on deferred taxes and goodwill. These findings combine to suggest that IFRS firms increase both the quantity and the level of detail of disclosure. To test whether private firms go beyond the disclosure requirements imposed by German law and IFRS, we finally measure the propensity of private firms to publish their financial reports voluntarily on the corporate website. We find that private firms adopting IFRS are significantly more likely to make their financial reports publicly available on corporate websites than their German GAAP counterparts. All of these results hold after controlling for a comprehensive set of firm characteristics and across all four firm types suggesting that IFRS adoption leads to increased disclosure. An important implication of these findings is that failure to identify earnings quality changes around IFRS adoption cannot be automatically interpreted as IFRS adoption having no effect on the FRQ of (private) firms.

Our paper contributes to the literature in several ways. First, to our knowledge we are the first to document both earnings quality and disclosure effects of voluntary IFRS adoption in the private firm setting. Thereby, we extend the literature investigating the consequences of voluntary IFRS adoption for FRQ in publicly listed firms (e.g., Barth et al. 2008). Second, we contribute to the research focusing on firm-level incentives as the source of heterogeneity in IFRS adoption effects (e.g., Daske et al. 2013; Christensen et al. 2015). Prior studies use relatively crude and abstract proxies for reporting incentives that are often limited in scope, or 
only used on an aggregated level and not necessarily related to actual reporting behaviour changes (see discussion in section 3.1). A novel aspect of our empirical approach is that we take into account interdependencies between numerous firm characteristics to identify different types of IFRS adopters and to put IFRS adoption into private firms' broader decision contexts. Our analysis by firm types highlights that simple dichotomous classifications of firms based on individual variables (e.g., size, leverage, sales growth) are only incomplete measures of reporting incentives. Third, we contribute to the small literature that compares earnings quality in private firms to public firms (Ball and Shivakumar 2005; Burgstahler et al. 2006) or examines heterogeneity within the group of privately held firms (e.g., Beuselinck et al. 2009; Haw et al. 2014; Hope et al. 2017). We present new evidence that FRQ of private firms varies considerably across firms depending on their reporting incentives and accounting standards. Finally, our findings suggest that failure to find IFRS adoption effects on one aspect of FRQ, e.g., earnings quality, cannot be interpreted as (private) firms adopting IFRS merely as a label. Rather, variation in reporting incentives appears to result in changes of different aspects of financial reporting around IFRS adoptions.

The paper is structured as follows. Section 2 describes the institutional setting. In section 3, we review the related literature and develop our hypotheses. Section 4 describes the sample selection procedure. Section 5 delineates the classification of IFRS adopting firm types. The results of the empirical analysis are presented in sections 6 (earnings quality) and 7 (disclosure practices). Section 8 concludes the paper.

\section{Institutional setting}

Germany is typically characterized as a code-law system with low investor protection and strong insider orientation. German GAAP are geared towards the contracting needs of creditors 
who have private information channels (Leuz and Wüstemann 2004). In contrast, IFRS cater more to the information needs of outsiders by promoting financial statements that are prepared for providing information that is useful in making economic decisions (IASB 2010). The different objectives of German GAAP and IFRS are reflected in the recognition and measurement rules of the two accounting systems. The dominant role of the prudence principle under German GAAP tends to (deliberately) understate assets and revenues, and overstate liabilities and expenses, which results in unconditionally conservative financial reports (e.g., Ball and Shivakumar 2005). ${ }^{3}$ For example, revenues generally can only be recognized in income if it is highly probable that they will be realized. The depreciation of property, plant and equipment is typically tax driven rather than based on the economic useful life of the asset. Unlike under IFRS, self-generated intangible assets cannot be recognized and purchased goodwill is amortized on a straight-line basis. The recognition of deferred tax assets is allowed, while the recognition of deferred tax liabilities is required. Furthermore, several accounting options allow for substantial reporting discretion (Joos and Lang 1994; Harris et al. 1994; Leuz and Wüstemann 2004). For example, German GAAP allows the recognition of expense provisions, which provide a convenient tool for income smoothing.

In contrast, consistent with their outsider orientation, IFRS aim to limit management's discretion in determining accounting amounts (Barth et al. 2008). Under IFRS, for example, expense provisions such as those under German GAAP must not be created. Impairment rules for financial instruments allow only the recognition of incurred losses, but not the provision for general unspecified risks (IAS 39). Other aspects in IFRS implement a certain degree of

Our discussion here is based on the German GAAP rules applicable until the end of 2009. A recent reform of German GAAP (through the Bilanzrechtsmodernisierungsgesetz), effective from January 1, 2010, aimed to reduce differences between IFRS and the revised German GAAP in many areas. This regulatory change affects only the final year of our sample period and is unlikely to affect our results. 
conservatism, such as the recognition of probable liabilities versus the non-recognition of contingent assets (IAS 37) or the impairment of long-lived assets (IAS 36) (André et al. 2015). Finally, IFRS require significantly more disclosure in financial reports than German GAAP (Daske and Gebhardt 2006). Given these substantial differences between German GAAP and IFRS, financial statement effects of IFRS adoptions are likely to be large in this setting. However, IFRS also provide a number of accounting options, which potentially mitigate financial reporting changes around IFRS adoption (e.g., Kvaal and Nobes 2010). ${ }^{4}$

Once a German private firm chooses to report under IFRS, it must apply the full set of standards, even if the decision to adopt IFRS is a voluntary decision. In addition, similar to publicly listed firms, certified auditors must verify the financial statements of (large) German private firms (Sect. 316 para. 2 HGB (German Commercial Code)). However, privately held firms are not subject to the formal enforcement mechanism established in 2005, unless they have securities issued on a regulated exchange in Germany (Sect. 342b para. 2 HGB). Given the lack of enforcement in the private firm setting, firm-specific characteristics likely have large effects on preparers' reporting incentives (Pope and McLeay 2011). However, the lack of enforcement might provide preparers and auditors with incentives to exploit the flexibility provided under IFRS to choose accounting options that minimise the number of changes to their accounting systems, thereby reducing the costs of transition to IFRS (Kvaal and Nobes 2010; Nobes 2013).

All German incorporated entities need to disclose their financial statements to the public by electronically filing them with the German corporate register (Elektronischer Bundesanzeiger) no later than 12 months after fiscal year-end (Sect. 325 para. 1 HGB). Thus,

4 For example, IAS 2 allows the first in first out (FIFO) or the weighted average method for inventory valuation; for investment property, IAS 40 allows the cost or the fair value method. 
archival data on the financial statements of German private firms are comprehensively available which allows us to study earnings quality and disclosure practices in the private firm setting.

\section{Related literature and hypotheses development}

\subsection{Voluntary IFRS adoptions and FRQ}

Although there is a substantial literature examining the FRQ effects and economic consequences of voluntary IFRS adoptions, most of the extant studies focus on publicly listed firms and provide mixed evidence (see Brüggemann et al. 2013 for an overview). Exploiting the German setting, Van Tendeloo and Vanstraelen (2005) compare the earnings management behaviour of voluntary IFRS adopters with that of firms reporting under German GAAP. They do not find differences in earnings management between German GAAP versus IFRS listed firms. In contrast, using a more comprehensive sample of German listed firms that adopted IFRS, Gassen and Sellhorn (2006) find that IFRS firms have more persistent, less predictable and more conditionally conservative earnings than a propensity score matched sample of German GAAP firms. Hung and Subramanyam (2007) also examine German voluntary IFRS adopters and exploit the fact that in the adoption year firms have to restate their comparative figures and compare accounting numbers prepared under German GAAP and IFRS. They find some evidence that IFRS income is more conditionally conservative, but not more value relevant than German GAAP income. In a cross-country study examining public IFRS adopters from 21 countries, Barth et al. (2008) document that IFRS adopters evidence less earnings management, more timely loss recognition and more value relevance of accounting amounts than a matched sample of firms reporting under domestic GAAPs. 
The above studies focus primarily on specific properties of earnings and/or their association with stock returns to evaluate the FRQ effects of IFRS adoption. By design, these metrics do not capture differences and changes in the information provided in actual annual reports. The study of Daske and Gebhardt (2006) stands out in that it examines the effect of IFRS and US GAAP on firms' disclosure quality. They use disclosure quality scores extracted from detailed analyses of annual reports by accounting experts for a comprehensive sample of Austrian, German and Swiss publicly listed firms. Daske and Gebhardt (2006) document that disclosure quality, as perceived by experts in their ratings of annual reports, increased significantly under IFRS in the three countries analysed.

We add to the above literature by investigating the voluntary IFRS adoption effects on earnings quality metrics and disclosure practices of private firms.

More recent studies document significant heterogeneity in IFRS adoption effects, but focus primarily on country-level variation and mandatory IFRS adoptions (e.g., Daske et al. 2008; Jeanjean and Stolowy 2008; Ahmed et al. 2013; André et al. 2015). However, the evidence on the role of firm-level incentives in the context of voluntary IFRS adoptions, the focus of our study, is scarce. Using the German setting, Christensen et al. (2015) examine IFRS adoption effects on the earnings quality of voluntary IFRS adopters versus mandatory IFRS adopters that were forced to comply with IFRS as of 2005. They find that earnings quality improvements in terms of less income smoothing, more timely loss recognition and increased value relevance are confined to firms with incentives to adopt IFRS, that is, voluntary IFRS adopters. Christensen et al. (2015) conclude that reporting incentives dominate accounting standards in shaping earnings quality. Daske et al. (2013) show that even voluntary IFRS adopters exhibit significant heterogeneity in their reporting incentives. They differentiate between "serious" versus "label" IFRS adopters using firm-level changes in reporting incentives, actual reporting behaviour and external reporting environment around IFRS adoption. Daske et al. (2013) 
document that capital market benefits of IFRS adoption, in the form of increased liquidity and reduced cost of capital, are confined to serious IFRS adopters. Their reporting incentives score, however, is only weakly correlated with the actual reporting behaviour variable. ${ }^{5}$ In other words, it remains unclear which firm attributes of the IFRS adopters are associated with changes in earnings quality in the first place. We complement these studies by using more intuitive measures of firms' reporting incentives to further our understanding of what drives reporting behaviour changes around IFRS adoptions in the private firm setting.

\subsection{Reporting incentives of private firms and FRQ}

In the public firm setting, the demand for financial reporting transparency arises primarily for two reasons (see Beyer et al. 2010). First, financial reporting information reduces ex ante information asymmetries between managers and (potential) capital providers and helps them to evaluate the profit potential of the firm (valuation role). Second, financial reporting information allows capital providers to monitor the use of their capital and thereby to mitigate ex post agency problems (stewardship role). Thus, firms' reporting incentives are determined by the relative importance of the valuation and stewardship role within the firm (Beyer et al. 2010).

However, information asymmetries and agency problems play typically only a minor role in private firms (Fama and Jensen 1985). Private firms are characterised by concentrated ownership with tight control over management where key stakeholders usually have access to information through private channels, which reduces the demand for transparent financial reporting (e.g., Hope et al. 2013). The main financiers of German private firms are banks with close relationships to the firms ("Hausbank"), often with a seat on their supervisory boards

\footnotetext{
5 The actual reporting behaviour variable is based on the ratio of accruals to cash flows, see Daske et al. (2013),
} p. 505. 
(Leuz and Wüstemann 2004). In fact, insiders (i.e., controlling owners and creditors) might benefit from opaque reporting because it protects their private benefits of control and information rents, respectively (Rajan and Zingales 1998). Consistent with this argument several papers show that earnings quality is lower for private than for public firms (Ball and Shivakumar 2005; Burgstahler et al. 2006; Hope et al. 2013) and income smoothing of German private firms increases with the importance of bank lending relationships (Gassen and Fülbier 2015; Bigus and Hillebrand 2017). Therefore, in addition to the relative importance of the valuation and stewardship problem the conflict between insiders and (potential) outsiders likely plays a role in shaping private firms' FRQ.

The literature examining heterogeneity of FRQ within private firms is scarce (Hope and Vyas 2017). Yet, private firms also exhibit substantial heterogeneity in their capital providers, including families, private equity investors, banks, bond holders, who face different agency and information problems that shape their financial reporting needs. Moreover, the financing and governance arrangements of private firms can change over time leading to a corresponding evolution of the role of financial reporting (Armstrong et al. 2010). For example, when private firms aim to raise external funds, e.g., through bond or equity IPOs, the valuation problem and reporting incentives to choose value maximizing reporting choices gain in importance. In support of this notion, Ball and Shivakumar (2008) find for a sample of UK private firms undergoing an equity IPO that they report more conservatively to reduce information asymmetries with outside investors. Haw et al. (2014) find similar results for Korean private firms that undergo public bond IPOs.

In addition, variation in the organizational and ownership structure of private firms can affect the magnitude of stewardship problems between owners and managers. For example, Bigus et al. (2016) find that incorporated German private firms exhibit higher levels of income smoothing and conservatism than partnerships and one-person businesses. Hope et al. (2017) 
find for US private firms that accrual quality is positively related to being organized as $\mathrm{C}$ corporation which are more likely to be managed by non-owners and are allowed to have an unlimited number of shareholders. Consistent with institutional owners' incentives to structure financial reporting in a way that maximizes the price at which they eventually sell the firm to outsiders, Beuselinck et al. (2009) show that Belgian private firms with PE ownership report more conservatively and engage less in earnings management than non-PE sponsored firms. Katz (2009) finds similar results for a sample of US private firms.

The disclosure practices of private firms have received even less attention in prior literature. Beuselinck et al. (2008) document for Belgian private firms a significant increase in voluntary financial disclosure following private equity participation. Examining private UK companies, Dedman and Lennox (2009) show empirically that managers are more concerned about revealing proprietary information when the potential for such disclosures to create competitive harm is high. Specifically, private companies are more likely to withhold sales and costs of sales information from their publicly-filed accounts when they face a higher degree of competition or are more profitable (Dedman and Lennox 2009). Further, particularly pertinent for our setting, Bernard et al. (2017) find that German private firms traditionally were reluctant to file their financial statements with the corporate register even when legally required to do so.

None of the above-mentioned studies is concerned with the effects of IFRS on private firms' FRQ. We complement this literature by examining the effect of IFRS adoption and firms' motivation to adopt on private firms' earnings quality and disclosure practices.

\subsection{IFRS firm types and FRQ}

Closely related to our paper are a few studies examining private firms' decisions to adopt IFRS (e.g., Francis et al. 2008; Bassemir 2017). Using survey data from the World Bank, 
Francis et al. (2008) find for an international sample of private firms that private limited liability companies (rather than sole proprietorships and partnerships), growth firms, larger firms, firms with greater external financing, firms with foreign owners and firms engaged in export activities, are more likely to adopt IFRS. Bassemir (2017) represents the most comprehensive analysis of voluntary IFRS adoptions in the private firm setting that uses actual financial statement data of German private firms. He finds that private firms with strong external financing needs (as indicated by high sales growth, IPOs and bond issuances), incorporated legal status, private equity ownership, larger share of international activities are more likely to adopt IFRS voluntarily. The paper also reviews the annual reports for selfdeclared motivations of sample firms to switch to IFRS and finds that enhanced comparability, higher transparency and quality of financial information as well as IPO readiness are major reasons cited for IFRS adoption.

The evidence in Francis et al. (2008) and Bassemir (2017) provides important insights and the starting point for our study, but it cannot directly speak to specific factors that drive earnings quality improvements around IFRS adoptions in private firms. Moreover, most of the prior studies reviewed in section 3.2 selectively focus on single corporate characteristics that theory predicts to lead to stronger reporting incentives. However, private firms experience significant changes in their characteristics along several dimensions simultaneously around IFRS adoptions (see section 5.1), which jointly determine the relative importance of the valuation and stewardship problems versus other considerations (e.g., insider-outsider conflict, comparability) in the IFRS adoption decision.

To capture the relative importance of the various motives for IFRS adoption, in this paper we take into account interdependencies among numerous characteristics of IFRS adopting firms, i.e., the costs and benefits of IFRS adoptions that have been identified by prior literature (e.g., Bassemir 2017). In particular, using factor and cluster analyses we identify specific firm 
types that are likely to vary with respect to valuation, stewardship and other (e.g., reputational) problems (see section 5.1 for the empirical implementation). We expect higher (improvements) in earnings quality particularly for firm types for which the valuation and/or the stewardship problems become more relevant.

As indicated earlier, a potential issue with earnings quality analyses is that they are prone to substantial measurement error. Specifically, managers can make a number of subtle and difficult-to-detect measurement choices that affect earnings quality metrics. In contrast, the room for discretionary disclosure choices is typically more limited (but not eliminated) under IFRS for two primary reasons. First, applicable IFRS contain specific guidance as to which financial information must be disclosed. Second, the (non-)compliance with disclosure requirements is easier to verify by the auditor, e.g., by using very detailed disclosure checklists. Combined with the more extensive disclosure requirements under IFRS, we generally expect a detectable increase in disclosure quantity and detail in the annual reports of IFRS adopting firms. Furthermore, if voluntary IFRS adopters are more committed to financial reporting transparency, we predict a higher propensity of IFRS firms to disclose their annual reports on the websites than German GAAP firms. Both of these effects will be more pronounced for the types of firms with greater valuation and/or stewardship problems.

\section{Sample selection and collection of data}

We start our sample selection with the August 2011 version of Hoppenstedt-Bilanzen that contains detailed financial statement information for all German firms filing their financial reports with the corporate register (Elektronischer Bundesanzeiger). We search for industrial firms (1) whose equity shares are not listed on a stock exchange and (2) which prepare consolidated financial statements. Our focus is on consolidated financial statements, because 
they have no legal implications for dividend distributions or taxes and exclusively serve informational purposes (Leuz and Wüstemann 2004). We do not include firms that are subsidiaries of other IFRS firms. Those firms are de-facto mandatory IFRS adopters, because they essentially have no choice in accounting standards and must comply with IFRS due to group accounting policies.

Our sample period starts in 1998, from which year the German Commercial Code allowed German private firms to replace German GAAP with IFRS for consolidated financial statements only, and ends in $2010 .{ }^{6}$ As Table 1 shows, applying these search criteria yields 3,328 unique firms including an initial sample of 345 IFRS firms. Based on these numbers, the overall proportion of German private parent firms adopting IFRS in their consolidated financial statements appears relatively small, with only ten percent of the investigated firms. However, when contrasted with prior research on public companies (see section 3.1), the (absolute) number of voluntary IFRS adopters is substantial. ${ }^{7}$

For each of these 345 firms, we manually collect information on whether it adopted IFRS as a private firm, the presence of a private equity investor, bond or profit participation certificate issuances, whether it has ever planned, underwent or cancelled an IPO during our sample period. As a result of this procedure, we delete 251 firms that adopted IFRS as listed entities and subsequently went private. Further, we add 87 firms that completed an IPO between 2001 and 2010 which offers us the possibility to study firms that were privately held

6 During this period IFRS changed particularly as a result of the 2001-2003 improvement project of the then newly formed IASB, in which thirteen International Accounting Standards (IAS) were revised and one IAS was withdrawn. The objective of these changes was to improve the quality of international accounting standards primarily by removing implicit or explicit accounting treatments and extending the amount of disclosures (https://www.iasplus.com/en/projects/completed/aip/project86). The revised standards have been effective since 1 January 2005. About 17 percent of our IFRS sample firms adopted IFRS before 2005. Since earlier IFRS allowed more discretion and required less disclosure, any noise stemming from the inclusion of these early adopters will bias against our predictions.

7 For example, the single-country study by Hung and Subramanyam (2007) uses 80 public IFRS firms. Covering 21 countries, the study of Barth et al. (2008) contains 327 public IFRS treatment firms. 
but decided to go public (IPO). German private firms that sell equity to the public regulated markets are required to adopt IFRS (starting from 2005) (Sect. 315a HGB). Nevertheless, we view IPO firms as voluntary IFRS adopters, since they could have chosen a market segment that does not require the application of IFRS (see also Gassen and Sellhorn 2006). Overall, these steps leave us with an initial sample of 3,164 firms (273 IFRS and 2,891 German GAAP firms).

\section{\{Insert Table 1 about here $\}$}

Data requirements further reduce the sample to a maximum of 228 IFRS firms and 1,986 German GAAP firms in the earnings quality analyses. For the disclosure analyses, we handcollect data from the financial reports of a propensity score-matched sample of German private firms. The financial reports are retrieved from firms' websites, if available, otherwise from the corporate register (Elektronischer Bundesanzeiger). Due to the costs associated with handcollection, the sample underlying the disclosure analyses is smaller. In total, we were able to collect disclosure information for a matched sample of 140 IFRS and German GAAP firms, respectively, for the period from 1998 to 2010. Depending on data availability, the number of observations can vary across our empirical tests. This is particularly due to a large number of IFRS adopters in our sample that do not have pre-adoption data available. Table 1 shows the different samples used in the subsequent empirical analyses.

\section{Identification of firm types and their reporting incentives}

\subsection{Identification of firm types}

This section describes how we use factor analysis and cluster analysis to classify IFRS adopters into different types. The initial inputs to the factor analysis are motivated by firm characteristics that prior literature found to be associated with a higher likelihood of IFRS 
adoption in the German private firm setting and private firms' self-proclaimed reasons for IFRS adoption (see Bassemir 2017, in particular Appendix A and B): firm size, profitability (return on assets), proxies for external financing needs and arrangements (e.g., sales growth, leverage, IPOs, bond and profit certificate issuances), corporate governance (e.g., legal form, PE ownership) and internationalization (percentage of foreign sales).

Figure 1 shows yearly changes in key firm characteristics during a 10-year period around IFRS adoption dates for a subset of firms, for which data is available both for the pre- and postadoption period. Average growth rates in total assets, foreign sales, and operating cash flow $(\mathrm{OCF})$ are increasing during the 10-year period, while leverage drops in the post-adoption period. The rise in total assets is particularly strong in the adoption year, which is likely due to mechanical accounting effects. This suggests that, on average, adopting firms make material changes to their accounting system in the adoption year rather than transition gradually to IFRS. ${ }^{8}$ With regard to the indicator variables, Figure 1 shows that bonds, IPO and private equity (PE) ownership occur more frequently in the three years starting with the adoption date than in other years. These results highlight that IFRS firms undergo substantial economic changes that are largely bundled around the time of IFRS adoption.

\section{\{Insert Figure 1 about here $\}$}

Since most of these economic changes are highly correlated with each other and jointly determine firms' reporting incentives and decision to adopt IFRS, it is difficult to draw conclusions based on a single characteristic (Bushee 1998). To mitigate this problem, we

8 Therefore, in our empirical analyses we exclude the IFRS adoption year. The notion that IFRS adopting firms make material changes to their accounting system is further substantiated by the analysis of reconciliation adjustments between German GAAP and IFRS for a sub-sample of 131 private firms where reconciliation numbers are available. Untabulated analyses show that a conversion from German GAAP to IFRS leads to a mean (median) change of 14.1 percent (9.3 percent) in total assets, of 14.8 percent (5.8 percent) in book value of equity, and of 4.6 percent (zero percent) in annual sales. The difference for total assets is significant using both t-test and Wilcoxon test, the difference for book value of equity is only significant using a Wilcoxon test, and the difference in sales is not statistically significant. 
perform a common factor analysis with an oblique rotation. ${ }^{9}$ Factor analysis extracts unobservable underlying factors (or constructs) from a large number of directly observable, interrelated variables. It explicitly examines the pattern of correlation among several observed variables to identify (distinct) groups of interrelated firm characteristics. This allows us to gain insight into different categories of IFRS adopting firms, making it easier and more intuitive to understand the complex construct of reporting incentives. Once common factors are identified, we calculate factor scores that are used in the subsequent cluster analysis.

Table 2 Panel A presents the factors identified through common factor analysis that we interpret as the main driving forces behind IFRS adoption. ${ }^{10}$ The first factor captures the equity market orientation of a firm. Firms with high scores on this factor are young, relatively small, with high external financing needs as indicated by high sales growth and a high propensity for an IPO, and a greater separation of ownership and control as indicated by their legal organization as stock corporations. The second factor relates to debt market orientation of a firm. Private firms that score high on this factor are large, externally rated and they have access to public bond markets. The third factor captures the relatively weak financial condition and PE ownership of a firm. Specifically, firms with high scores for this factor are highly leveraged, less profitable and PE owned. Finally, the fourth factor relates to internationalization and is high for firms with a large proportion of foreign sales, a Big5 auditor and operations in a medium- or high-tech industry.

\section{$\{$ Insert Table 2\}}

9 The common factor analysis has been previously used by accounting researchers in somewhat different contexts (Bushee 1998; Leuz 2000). We choose the oblique rotation to allow for correlation between factors.

10 For clarity, all factor loadings smaller than 0.3 in absolute terms are omitted. All factors but one has an eigenvalue of greater than 1 . Nevertheless, we retain four instead of three factors, because of better interpretability. The factor patterns of "Equity market orientation" and "Debt market orientation" remain similar, independent of the choice of the number of retained factors. 
In order to partition the sample into our final clusters or types of IFRS adopters, we perform $k$-means cluster analysis on the factor scores. Thereby, our goal is to identify firm types, which are similar in their reporting incentives within each type, but different across types. Panel B of Table 2 shows the result of the $k$-means cluster analysis and presents the means of the four factor scores and of all firm-specific variables for the four-cluster solution. Based on the mean factor scores, EQUITY firms' primary motivation for IFRS adoption is access to public equity markets. They are young (low Age) and fast growing (high Sales Growth). For DEBT firms factor scores indicate access to public bond markets and a large proportion of international activities as primary motivations. These firms are large (Size) and mature (high Age). FINCONPE firms are characterized by a weak financial condition and private equity ownership (highest and positive Financial Condition score). These firms probably have been taken over by PE investors in a leveraged buyout and are reorganized to prepare them for sale in the mid-term as indicated by the relatively large share of (planned) IPOs (29 percent). Finally, REPUTATION firms are internationally active (positive International activity) and in a very good financial condition (negative Financial condition).

Table 2 Panel $\mathrm{C}$ shows the distribution of post-adoption IFRS firm-years for the different types of IFRS adopting firms. It becomes apparent that while EQUITY firms started to adopt IFRS already in the early 2000s, most firms switched their accounting standards following the worldwide mandatory introduction of IFRS in 2005. Remarkably, there is a particularly significant jump in the frequency of IFRS adoptions by REPUTATION firms from 2005 onwards. Given that only a tiny portion of these firms is capital market oriented (see Table 2 Panel B), this adoption pattern is consistent with REPUTATION firms following the global trend of IFRS adoption and switching their accounting standards to achieve comparability with their international peers. 


\subsection{Reporting incentives of firm types}

An important question of our paper is how reporting incentives of firm types affect FRQ around voluntary IFRS adoptions. To assess the reporting incentives of the different firm types, we rely on the theoretical framework presented in section 3.2. and the descriptive characterizations of firm types in section 5.1. Specifically, we argue that the valuation and stewardship problems are highest in EQUITY firms, because of the entrance of outside investors and the largest separation of ownership and control. While DEBT firms face valuation problems with investors in the bond markets, stewardship problems are relatively low because of the tight control of family owners (as also indicated by the relatively low share of Stock Corporations in Table 2). In addition, controlling owners of these firms are often willing to accept higher cost of debt rather than to increase transparency to protect their private benefits of control. ${ }^{11}$

FINCON-PE firms face intermediate valuation problems because their PE owners typically want to sell their firms in the mid-term or take it public. However, the weak financial condition might incentivize them to smooth income in order to avoid the breach of financial covenants. Furthermore, the low level of stock corporations as legal form (only 12 percent) indicates that most of these firms are at a relatively early stage of their conversion into publicly listed firms. Stewardship problems are probably low, since PE owners typically have tight control over management. Finally, valuation and stewardship problems do not seem pervasive in REPUTATION firms since they rarely plan to engage in arm's length financing and are usually closely monitored by family owners. They might benefit from the application of IFRS

11 See, for example, the Handelsblatt (German business newspaper) article from 24 September 2012 titled "Wer die Börse meider, zahlt drauf" [in English: Who avoids the stock market, pays more]. 
by increasing the comparability between internationally active firms even without making significant changes to their financial accounting numbers (Hail et al. 2010).

Based on the arguments above, we expect incentives for high FRQ (improvements) after (around) IFRS adoption to be strongest in EQUITY firms, medium in the "in-between" clusters DEBT and FINCON-PE and lowest in REPUTATION firms.

\section{Empirical analyses of earnings quality}

\subsection{Methodology and measurement of earnings quality}

We operationalize earnings quality using several earnings management and timely loss recognition metrics (e.g., Lang et al. 2006; Barth et al. 2008; Christensen et al. 2015). Consistent with prior studies and the outsider orientation of IFRS, we assume that, ceteris paribus, lower levels of earnings management and more timely loss recognition indicate higher earnings quality. We conduct two sets of tests. In the first set of tests, we are interested in whether the earnings quality of different types of IFRS adopters varies in the predicted ways and how their earnings quality compares to the average German GAAP firm. We face the limitation that many of our IFRS adopters do not have data available in the pre-adoption period. Therefore, we conduct one cross-sectional test comparing the earnings quality of different types of IFRS adopters in the post-adoption period with each other and with the average earnings quality of a comprehensive (unmatched) sample of German GAAP firms during the sample period. Subsequently, we run a within-firm analysis for each IFRS firm type to gauge changes in earnings quality around the accounting switch, effectively using each firm as its own control.

In our second set of analyses, we attempt to isolate the incremental effect of IFRS on firms' earnings quality. Towards this end, we apply the propensity score method to match our IFRS 
firm types with German GAAP firms. For example, to match EQUITY firms, we first calculate propensity scores for each German GAAP firm based on the conditional probability of being an EQUITY firm. The score is computed in a probit model where we include the whole set of variables also used in the factor analysis as conditioning variables (see Table 2). We then match each EQUITY firm with a German GAAP firm with the closest propensity score, without replacement. We repeat this procedure for all firm types. A drawback of matching is that it significantly reduces the sample size, making it impossible to run the earnings quality analyses by firm types. Therefore, we compare the earnings quality of the pooled IFRS sample with that of the matched German GAAP counterparts. Again, one test is a cross-sectional comparison using post-adoption observations only, and another test is a within-firm analysis of earnings quality changes around IFRS adoption for a smaller sample with both pre- and post-adoption data available. Finally, the matched design also allows for a differences-in-differences analysis.

We examine two types of earnings management, earnings smoothing and managing towards small positive earnings. In line with Barth et al. (2008), we measure earnings smoothing using the following three empirical constructs: variability of changes in earnings, the standard deviation of changes in earnings relative to the standard deviation of changes in cash flows, and the correlation between accruals and cash flows. The idea behind these measures is that earnings that do (not) recognize economic gains and losses on a timely basis should exhibit higher (lower) earnings variability, higher variability of earnings relative to the variability of cash flows and a less negative correlation between accruals and cash flows. We expect that firms engaging less in income smoothing behaviour exhibit higher earnings variability (e.g., Lang et al. 2006; Barth et al. 2008). Furthermore, Ball and Shivakumar (2005) suggest that timely gain and loss recognition results in higher variability of earnings relative to 
cash flows. Finally, we assume that a more negative correlation between accruals and cash flows is reflective of income smoothing behaviour. ${ }^{12}$

In order to construct our empirical metrics, we follow the methodology outlined in Barth et al. (2008) which we detail in the Appendix.

\subsection{Descriptive statistics for the variables used in the earnings quality analyses}

Table 3 Panel A contains descriptive statistics on the test variables and the firm-specific characteristics for the full IFRS and German GAAP samples over the entire sample period from 1998 to 2010 . The descriptive statistics on the test variables are largely comparable to those reported in Barth et al. (2008) and Christensen et al. (2015). Most notably, IFRS firms have significantly smaller accruals (as indicated by ACC), significantly fewer incidents of small profits (SPOS) and significantly more incidents of large losses (LNEG) than German GAAP firms. Table 3 further reveals that IFRS adopters are larger (Size), more likely to be registered as stock corporation (Stock Corporation), have more international sales (Foreign Sales), more likely to be characterized by private equity involvement (PE Ownership), more leveraged (Leverage), growing faster (Sales Growth), and more likely to raise external capital by issuing public bonds or equity (Bonds or IPO) than German GAAP firms. These results are consistent with prior research on the determinants of voluntary IFRS adoptions (e.g., Dumontier and Raffournier 1998; Bassemir 2017).

\{nsert Table 3\}

Table 3 Panel B reports the comparison of the same test variables and covariates for the matched sample of IFRS and German GAAP firms. It appears that we are partially successful

12 While a negative correlation is expected due to the role of accounting accruals to smooth the variability of cash flows (Dechow 1994), excessive values are generally interpreted to be indicative of earnings management (e.g., Burgstahler et al. 2006; Myers et al. 2007). In contrast, more timely gain and loss recognition should attenuate the negative correlation between accruals and cash flows (Ball and Shivakumar 2005). 
in reducing differences between the two groups of firms, as the similarity for most of the covariates increases (e.g., size, foreign sales, medium and high tech industry, leverage), but statistical differences still remain. This highlights the general issue of a limited number of good matching candidates in a single-country setting (Christensen et al. 2015). To mitigate the impact of these differences on earnings quality, we include all the covariates as control variables when constructing our earnings quality metrics.

\subsection{IFRS firm types and earnings quality}

Table 4 Panel A reports the results for the comparison of earnings quality by different types of firms in the post-IFRS-adoption period and with the average earnings quality of German GAAP firms over the sample period. ${ }^{13}$ Results indicate that firms in the EQUITY cluster exhibit higher earnings quality than German GAAP firms. Specifically, EQUITY firms engage less in income smoothing behaviour as reflected in a higher earnings variability $(0.0085$ versus 0.0035$)$, higher variability of earnings relative to variability of cash flows ( 0.7535 versus $0.6485)$ and a less negative correlation between accruals and cash flows (-0.6956 versus 0.7509). These results are also statistically significant. Furthermore, as indicated by the negative and significant coefficient on SPOS both in the standard regression (-0.0066) and in the Reverse regression (-0.0237), EQUITY firms manage less frequently towards small positive profits than German GAAP firms. LNEG is positive and highly significant, indicating more timely loss recognition relative to German GAAP firms.

\section{$\{$ Insert Table 4\}}

Firms belonging to the DEBT cluster generally do not appear to have a higher earnings quality than German GAAP firms, at least in terms of income smoothing. They show

13 We also report results using the raw variables $(\triangle N I, \triangle C F, A C C, C F)$ as inputs for the computation of our earnings quality proxies rather than their residuals. Since results are very similar, we focus our discussion on the metrics based on residuals, which are indicated with a star. 
significantly lower earnings variability $(0.0014$ versus 0.0035$)$ and a significantly lower ratio of earnings variability relative to cash flow variability (0.4146 versus 0.6485$)$ than German GAAP firms. The correlation between accruals and cash flows is insignificantly less negative for DEBT firms (-0.7535 versus -0.7509). The coefficient on SPOS is negative $(-0.0171$; 0.0966 in the Reverse regression) and statistically significant suggesting that DEBT firms engage less in earnings management by turning small losses into small profits. The coefficient on LNEG is positive (0.0077), but insignificant, indicating no significant differences in timely loss recognition between DEBT and German GAAP firms.

Firms in the FINCON-PE cluster exhibit significantly higher earnings variability than German GAAP firms (0.0064 versus 0.0035). However, while the differences in the other metrics also indicate higher earnings quality for FINCON-PE firms, the results are statistically insignificant.

Finally, REPUTATION firms do not differ significantly from German GAAP firms in terms of income smoothing. Except for earnings variability, REPUTATION firms have a higher ratio of volatility of earnings to volatility of cash flows (0.6979 versus 0.6485$)$, and a less negative correlation between accruals and cash flows (-0.7259 versus -0.7509$)$, though none of the results is statistically significant. The coefficients on SPOS and LNEG have the expected signs, but only SPOS $(-0.0161 ;-0.0611$ in the Reverse regression) is significantly different from zero suggesting that REPUTATION firms manage earnings less towards small profits.

In the right part of Table 4 Panel A, we report direct comparisons of earnings quality across different types of firms. Generally, based on our empirical proxies EQUITY firms appear to have the highest earnings quality consistent with these firms facing the greatest demand for high FRQ. Contrary to our expectations, DEBT firms exhibit the lowest earnings quality probably because their controlling owners prefer less reporting transparency to protect their 
private benefits of control. Overall, these findings are consistent with different reporting incentives across the different types of IFRS adopting firms, but there is little evidence that IFRS firms in general have higher earnings quality than average German GAAP firms.

Although the previous findings suggest that only EQUITY firms exhibit consistently higher earnings quality, it is possible that upon IFRS adoption all adopting firms experience an improvement in earnings quality relative to German GAAP accounting. Specifically, due to their changing economics, these firms might have been constrained in portraying their economic performance under German GAAP and they can mitigate this problem by adopting IFRS. In order to investigate this further, we perform a pre- and post-adoption analysis for the different IFRS firm types for which data are available.

Table 4 Panel B reveals that EQUITY firms evidence the most significant improvements in earnings quality. In particular, the variability of earnings and the variability of earnings relative to the variability of cash flows increase, while the negative correlation between accruals and cash flows is reduced in the post-adoption period. These changes are statistically significant and imply reduced earnings management. The insignificant results for SPOS and LNEG are likely due to lack of power given the small sample size. ${ }^{14}$ In contrast, DEBT and FINCON-PE firms do not exhibit improvements in their earnings quality. Interestingly, REPUTATION firms show significant improvements in two of the three income smoothing metrics and a lower incidence of small positive profits in the post-adoption period. Taken together with the findings in Panel A, these results suggest that REPUTATION firms have lower earnings quality than average German GAAP firms in the pre-adoption period, but catch up after the adoption of IFRS. One interpretation of these findings is that these firms are better

14 The Reverse specifications of SPOS and LNEG yield similar results across all clusters in the Pre-Post analyses. Therefore, we do not present them separately in Panel B of Table 4. 
able to show economic performance in financial statements by applying IFRS, because they were constrained in their German GAAP reporting.

In sum, these results suggest that different motivations to adopt IFRS yield different earnings quality effects. Importantly, the results by firm types imply that individual variables like size, leverage, sales growth, and profitability are only incomplete measures of reporting incentives. For example, individually, larger size or higher leverage is generally associated with stronger reporting incentives. However, in our study it is the smallest firms with the lowest leverage that experience the most significant changes in reporting behaviour. This highlights the importance of examining the interrelation between different incentive variables.

\subsection{The incremental effect of IFRS on earnings quality}

Some of the previous results suggest that IFRS adoption might help firms to better portray their economic performance. In this section, we attempt to identify the incremental effect of IFRS using a matched sample design. Table 5 Panel A presents the comparison of earnings quality for matched IFRS and German GAAP firms in the post-adoption period. For brevity, we focus our discussion on the main implications of the results. They generally indicate that IFRS adopting firms have (marginally) higher earnings quality than German GAAP firms. Specifically, IFRS firms evidence less income smoothing, less earnings management toward small net income, and more timely loss recognition. However, findings for the correlation between accruals and cash flows are statistically insignificant.

In Table 5 Panel B, we turn to the comparison of earnings quality changes around IFRS adoption for IFRS and German GAAP firms. As regards the income smoothing metrics, IFRS firms generally exhibit less smoothing after IFRS adoption. In contrast, the control firms show the same level of income smoothing. The coefficient on small positive profits is negative for IFRS and positive for German GAAP in both the standard Barth et al. (2008) and the Reverse 
specification, but these results are statistically insignificant. Finally, the frequency of large negative net income is significantly higher in the post-adoption period for IFRS adopting firms, but not for the control group.

\{Insert Table 5 about here $\}$

Finally, Table 5 Panel $\mathrm{C}$ reports the results for the differences-in-differences analysis. The signs of the differences generally indicate that IFRS firms evidence larger improvements in earnings quality than German GAAP firms. However, most of the findings are statistically insignificant, which is likely to be attributable to low statistical power arising from estimation error (Barth et al. 2008). Taken together, the results in Table 5 are consistent with the notion of accounting standards (IFRS) having an effect on private firms' earnings quality. However, even though we match firms on a number of observables and include them as controls in constructing our earnings quality metrics, we cannot rule out the possibility that the remaining differences in the covariates drive our findings. Therefore, these results should be interpreted with caution.

\section{Empirical analyses of disclosure quality}

Taken at face value our findings so far might suggest that most (non-EQUITY) IFRS private firms adopt IFRS merely as a label, because they do not exhibit significant changes in their earnings properties. However, at least two objections can be made against this argument. First, as outlined before, IFRS adoption can still make financial statements more informative, if it increases comparability with other IFRS peer firms. Second, and more importantly, the earnings quality metrics used above only insufficiently capture overall FRQ of private firms. To address the latter issue, we compare disclosure practices of IFRS adopting firms with that of German GAAP firms for the matched sample. 


\subsection{Methodology}

\subsubsection{Disclosure proxies}

We construct three sets of proxies to measure the disclosure practices of private firms. First, we count the number of pages for the annual report (AR Pages), the notes (Notes Pages) as well as the management discussion and analysis (MD\&A) section (MD\&A Pages). Second, since page numbers is a crude (albeit often used) proxy and potentially influenced by boilerplate-type disclosure, we further construct a Disclosure_Content1 score to capture the level of disclosure detail. Thereby we focus on deferred taxes and goodwill, two financial items that are particularly different in their accounting treatment under IFRS and German GAAP. Disclosure_Content1 is computed as the sum of eight dummy variables indicating whether deferred taxes and goodwill are presented on the balance sheet (deferred_tax_presented and goodwill_presented), whether the deferred taxes and goodwill are explained in the notes (deferred_tax_expl_notes and goodwill_expl_notes), whether the number of pages spent on explaining the deferred tax item and goodwill in the notes are above the sample median (deferred_tax_pages > sample median and goodwill_expl_pages > sample median), whether there is a breakdown into deferred tax assets and liabilities (deferred_tax_breakdown), whether the average tax rate applicable to the company is disclosed (tax_rate_disclosed). We also compute Disclosure_Content 2 only for firm observations where the notes contain information on deferred taxes (i.e., deferred_tax_expl_notes $=1$ ) and on goodwill (i.e., goodwill_expl_notes $=1$ ). This more restricted score aims to compare only those firm observations where both deferred tax and goodwill are sufficiently significant accounting items to be discussed in the notes.

Third, we create a dummy variable, Website, taking the value of 1 for firms that publish their financial report on their website, and zero otherwise. We use this dummy variable to test 
whether IFRS firms go beyond legal disclosure requirements that mandate firms to file their financial reports with the German corporate register. ${ }^{15}$

\subsubsection{Multivariate regression design}

We first estimate the following OLS model for the post-adoption period for the matched sample of IFRS and German GAAP firms:

$$
\text { Disclosure }=\beta_{0}+\beta_{1} \text { IFRS }+\beta_{2} \text { Website }+\sum \beta_{j} \text { Controls }_{j}
$$

Disclosure stands for the first two sets of continuous proxies capturing the quantity and detail of disclosure (i.e., AR Pages, Notes Pages, MD\&A Pages, Disclosure Content1, Disclosure Content2). IFRS is a dummy variable coded as 1 (0) for IFRS adopting (German GAAP) firms. We also include the dummy variable Website to control for the fact that annual reports published on firms' websites can contain marketing, advertising and other non-financial information, while reports published through the Elektronischer Bundesanzeiger do not. Controls $s_{j}$ denotes all firm-specific variables from Table 2, since they have been found to be associated with firms' disclosure choices (e.g., Leuz 2000; Beuselinck et al. 2008), industryand year-fixed effects. In addition, we include Capital intensity, computed as net property plant and equipment divided by total assets, to proxy for proprietary costs of disclosure (e.g., Leuz 2000). We run equation (1) for the pooled sample and the different firm types separately.

For firms with pre- and post-adoption data available, we perform a differences-indifferences test by including a Post dummy, coded as 1 (0) for years after (before) IFRS adoption, and the interaction term IFRS*Post in equation (1). In this specification, the coefficient on the interaction term captures the extent disclosures have changed for IFRS firms in the post-adoption period relative to the matched German GAAP firms.

15 Firms whose equity or debt is traded on a regulated market must publish their reports on the corporate website. We take this into account in our multivariate analyses. 
Finally, to test whether IFRS firms have a higher propensity to publish their financial reports on their websites than German GAAP firms, we estimate the following probit model (due to limited data availability only for the post-adoption period):

$$
\text { Website }=\beta_{0}+\beta_{1} \text { IFRS }+\sum \beta_{j} \text { Controls }_{j}
$$

\subsection{Descriptive statistics of disclosure variables}

Table 6 reveals that the total number of pages of the annual report amounts to 82 in the mean for IFRS firms, while this number corresponds to only 31 for the German GAAP sample. In addition, the notes and the MD\&A sections include 32 and 16 pages in the mean for the IFRS firms, respectively, which is considerably higher than for the German GAAP firms (7 pages, respectively). ${ }^{16}$ Furthermore, the disclosure content scores are significantly higher for IFRS firms suggesting that their financial reports contain more detail regarding deferred taxes and goodwill than German GAAP reports.

\{Insert Table 6 about here $\}$

As Table 6 further shows, 56 percent of IFRS firms publish the financial report on their website, which is a significantly higher share than for German GAAP firms (23 percent). Not surprisingly, primarily EQUITY and DEBT IFRS firms make their financial reports available online. For FINCON-PE firms there is no significant difference between IFRS and German GAAP firms. However, REPUTATION firms are significantly more likely to put their reports on the website than their matched German GAAP counterparts.

16 These large differences are to some extent attributable to the fact that annual reports published on websites are significantly longer than those submitted to the Elektronischer Bundesanzeiger. We take this into account in our multivariate analyses. 


\subsection{Multivariate disclosure analyses}

Models (1) to (3) of Table 7 report results on the quantity of disclosures provided in the financial reports of IFRS versus German GAAP firms in the post-adoption period. Panel A shows that financial reports as well as notes sections contained in the financial reports of IFRS firms are significantly longer (as measured by page number) than those of German GAAP firms. These results are reinforced by Panel B indicating that each type of IFRS adopters has longer annual reports and notes sections than their German GAAP counterparts. ${ }^{17}$ The comparison across incentive clusters does not show a consistent pattern for the length of the annual report (sections). IFRS firms generally do not have significantly longer MD\&A sections than German GAAP firms (Panel A), except for DEBT and FINCON-PE firms (Panel B). However, this is not surprising given that the inclusion of MD\&A is not an IFRS-specific requirement. Overall, these results show increased disclosure by IFRS firms which is likely to be attributable to the stronger IFRS disclosure requirements that provide less room for managerial discretion and are easier to verify for auditors by using checklists (compared to earnings metrics). However, the use of checklists bears the risk of a "tick box" mentality, where firms merely increase boilerplate disclosure (Daske et al. 2013; Christensen et al. 2015).

\{Insert Table 7 about here\}

Therefore, in Models (4) and (5) of Table 7 we test whether IFRS firms also increase the level of detail of disclosure. As indicated by the positive and significant coefficients on Disclosure_Content1 and Disclosure_Content2 in Panel A, IFRS financial reports contain significantly more detailed information in the notes than German GAAP financial reports. Panel B shows that each type of IFRS adopters provides more detail in their notes sections

17 In Panel B, because of high correlation, we exclude IPO in the EQUITY cluster, rating and bonds in the DEBT cluster, and peown in the FINCON-PE cluster. For presentational purposes, we only display the results for the IFRS coefficient for each cluster and regression, respectively. 
relative to their German GAAP counterparts. ${ }^{18}$ It also reveals that the difference in disclosure detail (Disclosure_Content1 and Disclosure_Content2) is most (least) pronounced for EQUITY (REPUTATION) firms, consistent with these firms having stronger (weaker) reporting incentives.

Table 8 shows the results for a differences-in-differences analysis of the disclosure practices of IFRS firms with that of German GAAP firms. We find that adopting firms increase the amount and detail of disclosure specifically in the post-adoption period (positive and significant coefficient on IFRS*Post, except for MD\&A). ${ }^{19}$ In untabulated regressions we find similar results when we exclude EQUITY and DEBT firms, suggesting that increased disclosure following IFRS adoption is not solely driven by capital market oriented firms. In sum, the findings from Table 7 and 8 suggest that IFRS firms increase both the quantity and the level of detail of disclosure.

$\{$ Insert Table 8 about here $\}$

Table 9 shows that IFRS firms are more likely to publish their financial reports online than German GAAP firms in the post-adoption period (Model (1)). Furthermore, Models (2) to (5) indicate that across all clusters IFRS firms have higher propensities to use their website as a disclosure channel for their financial reports. ${ }^{20}$ Notably, the result for REPUTATION firms suggests that even in the absence of (expected) capital market transactions IFRS firms are more likely to make annual reports available on their website than German GAAP firms. Overall, these findings can be interpreted as private firms committing to transparency, especially against

18 In Panel B, because of high correlation with the IFRS dummy, we exclude IPO in the EQUITY cluster, rating and bonds in the DEBT cluster, and peown in the FINCON-PE cluster. For presentational purposes, we only display the results for the IFRS coefficient for each cluster and regression, respectively.

19 Because of the small sample size, we cannot run this analysis for each cluster separately.

20 Due to high correlation with the IFRS dummy, we exclude IPO for the EQUITY firms (Model (2)), rating and bonds for the DEBT firms (Model (3)), and peown in the FINCON-PE cluster. 
the background that German private firms historically were reluctant to make their annual reports public even when they were legally required to so (Bernard et al. 2017).

Taken together, the results of our disclosure analyses suggest that all IFRS firms improve their disclosure in terms of quantity and level of detail following the accounting switch. These findings mitigate the concern that private firms merely adopt a label, as one might conclude from our earnings quality analyses. However, the observed changes in disclosures are not only the effect of the increased disclosure requirements under IFRS, but also the result of a greater commitment to transparency of IFRS firms as evidenced by the greater willingness to publish annual reports on their websites.

\{Insert Table 9 about here

\section{Conclusions}

In this paper we investigate FRQ of German private firms around the voluntary adoption of IFRS across two dimensions, earnings quality and disclosure practices. We are particularly interested in the financial reporting consequences of the different motivations of private firms to adopt IFRS. To gauge private firms' motivations for IFRS adoption empirically, we use factor and cluster analyses based on a comprehensive set of firm characteristics and observable economic events that occur concurrently around IFRS adoption. We identify four types of firms that differ primarily in the level of capital market orientation, life cycle, internationalization, corporate governance (as captured by legal form and ownership type), and financial condition.

Our results indicate that higher earnings quality (improvements) are confined to one type of firms that are young, fast growing and seeking immediate access to the public equity markets consistent with these firms benefitting most from increasing transparency. Recognizing that our earnings quality metrics are only incomplete measures of reporting quality, we additionally compare the disclosure practices of IFRS and German GAAP firms. Our results show that IFRS 
adopting firms are more likely to publish the financial reports on their website and they significantly increase the quantity and detail in disclosure. An important implication of this finding is that failure to identify changes of particular aspects of earnings quality around IFRS adoption cannot be per se interpreted as (private) firms generally not improving their FRQ.

Taken together, our earnings quality and disclosure tests suggest that IFRS adopting firms increase FRQ relative to German GAAP reporting firms. However, different incentives for the adoption decision result in firms changing different dimensions of FRQ presumably to tailor the financial report to the different information needs of the respective stakeholders. 


\section{REFERENCES}

Ahmed, A., M. Neel, and D. Wang (2013), 'Does Mandatory Adoption of IFRS Improve Accounting Quality? Preliminary Evidence', Contemporary Accounting Research, Vol. 30, No. 4, pp. 1344-1372.

André, P., A. Filip, and L. Paugam (2015), 'The Effect of Mandatory IFRS Adoption on Conditional Conservatism in Europe', Journal of Business Finance \& Accounting, Vol. 42, Nos 3-4, pp. 482-514.

Armstrong, C. S., W. R. Guay, and J. Weber (2010), 'The role of information and financial reporting in corporate governance and debt contracting', Journal of Accounting and Economics, Vol. 50, No. 2, pp. 179-234.

Ball, R., A. Robin, and J. S. Wu (2003), 'Incentives versus standards: properties of accounting income in four East Asian countries', Journal of Accounting and Economics, Vol. 36, No. 1, pp. 235-270.

Ball, R., and L. Shivakumar (2005), 'Earnings Quality in Private UK Firms: Comparative Loss Recognition Timeliness', Journal of Accounting and Economics, Vol. 39, No. 1, pp. 83-128.

Ball, R., and L. Shivakumar (2008), 'Earnings Quality at Initial Public Offerings', Journal of Accounting and Economics, Vol. 45, No. 1, pp. 324-349.

Barth, M. E., W. R. Landsman, and M. H. Lang (2008), 'International Accounting Standards and Accounting Quality', Journal of Accounting Research, Vol. 46, No. 3, pp. 467-498.

Bassemir, M. (2017), 'Why Do Private Firms Adopt IFRS?', Accounting and Business Research, Forthcoming.

Bernard, D., D. Burgstahler, and D. Kaya (2017), 'Disclosure Incentives and Data Availability for Private Firms: Implications for Comparisons of Public and Private Firm Financial Reporting Quality', Working paper, University of Washington.

Beuselinck, C., M. Deloof, and S. Manigart (2008), 'Private Equity Investments and Disclosure Policy', European Accounting Review, Vol. 17, No. 4, pp. 607-639.

Beuselinck, C., M. Deloof, and S. Manigart (2009), 'Private Equity Involvement and Earnings Quality', Journal of Business Finance and Accounting, Vol. 36, Nos. 5-6, pp. 587-615.

Beyer, A., D. Cohen, T. Lys, and B. Walter (2013), 'The Financial Reporting Environment: Review of the Recent Literature', Journal of Accounting and Economics, Vol. 50, No. 2, pp. 296-343.

Bigus, J., N. Georgiou, and P. Schorn (2016), 'Legal Form and Earnings Properties', European Accounting Review, Vol. 25, No. 3, pp. 515-548.

Bigus, J., and C. Hillebrand (2017), 'Bank Relationships and Private Firms' Financial Reporting Quality', European Accounting Review, Vol. 26, No. 2, pp. 379-409. 
Brüggemann, U., J.-M. Hitz, and T. Sellhorn (2013), 'Intended and unintended consequences of mandatory IFRS adoption: A review of extant evidence and suggestions for future research', European Accounting Review, Vol. 22, No. 1, pp. 1-37.

Burgstahler, D., L. Hail, and C. Leuz (2006), 'The Importance of Reporting Incentives: Earnings Management in European Private and Public Firms', The Accounting Review, Vol. 81, No. 5, pp. 983-1016.

Bushee, B. J. (1998), 'The Influence of Institutional Investors on Myopic R\&D Investment Behavior', The Accounting Review, Vol. 73, pp. 305-333.

Christensen, H. B., E. Lee, M. Walker, and C. Zeng (2015), 'Incentives or Standards: What Determines Accounting Quality Changes Around IFRS Adoption?', European Accounting Review, Vol. 24, No. 1, pp. 31-61.

Daske, H., and G. Gebhardt (2006), 'International Financial Reporting Standards and Experts' Perceptions of Disclosure Quality’, Abacus, Vol. 42, Nos. 3-4, pp. 461-498.

Daske, H., L. Hail, C. Leuz, and R. Verdi (2008), 'Mandatory IFRS Reporting around the World: Early Evidence on the Economic Consequences', Journal of Accounting Research, Vol. 46, No. 5, pp. 1085-1142.

Daske, H., L. Hail, C. Leuz, and R. Verdi (2013), 'Adopting a Label: Heterogeneity in the Economic Consequences of IFRS adoptions', Journal of Accounting Research, Vol. 51, pp. 495-547.

Dechow, P. M. (1994), 'Accounting Earnings and Cash Flows as Measures of Firm Performance: The Role of Accounting Accruals', Journal of Accounting and Economics, Vol. 18, No. 1, pp. 3-42.

Dedman, E., and C. Lennox (2009), 'Perceived competition, profitability and the withholding of information about sales and the cost of sales', Journal of Accounting and Economics, Vol. 48, No. 2, pp. 210-230.

Dumontier, P., and B. Raffournier (1998), 'Why firms comply voluntarily with IAS: an empirical analysis with Swiss data', Journal of International Financial Management and Accounting, Vol. 9, No. 3, pp. 216-245.

Fama, E., and M. Jensen (1985), 'Organizational Forms and Investment Decisions', Journal of Financial Economics, Vol. 14, No. 1, pp. 101-119.

Francis, J., I. K. Khurana, X. Martin, and R. Pereira (2008), 'The Role of Firm-Specific Incentives and Country factors in Explaining Voluntary IAS Adoptions: Evidence from Private Firms', European Accounting Review, Vol. 17, No. 2, pp. 331-360.

Gassen, J., and R. U. Fülbier (2015), 'Do creditors prefer smooth earnings? Evidence from European private firms', Journal of International Accounting Research, Vol. 14, No. 2, pp. 151-180. 
Gassen, J., and T. Sellhorn (2006), 'Applying IFRS in Germany-Determinants and Consequences', Betriebswirtschaftliche Forschung und Praxis, Vol. 58, pp. 365-386.

Hail, L., C. Leuz, and P. Wysocki (2010), 'Global Accounting Convergence and the Potential Adoption of IFRS by the U.S. (Part I): Conceptual Underpinnings and Economic Analysis', Accounting Horizons, Vol. 24, No. 3, pp. 355-394.

Haw, I-M., J. J. Lee, and W-J. Lee (2014), 'Debt Financing and Accounting Conservatism in Private Firms', Contemporary Accounting Research, Vol. 31, No. 4, pp. 1220-1259.

Hope, O. K., W. Thomas, and D. Vyas (2013), 'Financial Reporting Quality of US Private and Public Firms', The Accounting Review, Vol. 88, No. 5, pp. 1715-1742.

Hope, O. K., W. Thomas, and D. Vyas (2017), 'Stakeholder demand for accounting quality and economic usefulness of accounting in U.S. private firms', Journal of Accounting and Public Policy, Vol. 36, No. 1, pp. 1-13.

Hope, O. K. and D. Vyas (2017), 'Private company finance and financial reporting', Accounting and Business Research, Vol. 47, No. 5, pp. 506-537.

Hribar, P. and D. W. Collins (2002), 'Errors in Estimating Accruals: Implications for Empirical Research', Journal of Accounting Research, Vol. 40, No. 1, pp. 105-134.

Hung, M. and K. Subramanyam (2007), 'Financial Statement Effects of Adopting International Accounting Standards: the Case of Germany', Review of Accounting Studies, Vol. 12, No. 4, pp. 623-657.

International Accounting Standards Board (IASB) (2010), The Conceptual Framework for Financial Reporting. London.

Jeanjean, T., and H. Stolowy (2008), 'Do Accounting Standards Matter? An Exploratory Analysis of Earnings Management before and after IFRS Adoption', Journal of Accounting and Public Policy, Vol. 27, No. 6, pp. 480-494.

Joos, P., and M. Lang (1994), 'The Effects of Accouting Diversity. Evidence from the European Union', Journal of Accounting Research, Vol. 32, pp. 141-168.

Katz, P. S. (2009), 'Earnings Quality and Ownership Structure: The Role of Private Equity Sponsors', The Accounting Review, Vol. 84, No. 3, pp. 623-658.

Kvaal, E. and C. Nobes (2010), 'International differences in IFRS policy choice: A research note', Accounting and Business Research, Vol. 40, No. 2, pp. 173-187.

Lang, M., J. S. Raedy, and W. Wilson (2006), 'Earnings Management and Cross Listing: Are Reconciled Earnings Comparable to US Earnings? ', Journal of Accounting and Economics, Vol. 42, No. 1, pp. 255-283. 
Leuz, C. (2000), 'The Development of Voluntary Cash Flow Statements in Germany and the Influence of International Reporting Standards', Schmalenbach Business Review, Vol. 52, pp. 182-207.

Leuz, C. (2003), 'IAS Versus U.S. GAAP: Information Asymmetry-Based Evidence from Germany's New Market', Journal of Accounting Research, Vol. 41, No. 3, pp. 445-472.

Leuz, C, D. Nanda and P. Wysocki (2003), 'Earnings Management and Investor Protection: An International Comparison', Journal of Financial Economics, Vol. 69, No. 3, pp. 505527.

Leuz, C., and R. E. Verrecchia (2000), 'The Economic Consequences of Increased Disclosure', Journal of Accounting Research, Vol. 38, No. 3, pp. 91-124.

Leuz, C., and J. Wüstemann (2004), 'The Role of Accounting in the German Financial System', in J.-P. Krahnen and R. H. Schmidt (eds), The German Financial System, Oxford, pp. 450485 .

Nobes, C. (2013), 'The continued survival of international differences under IFRS', Accounting and Business Research, Vol. 43, No. 2, pp. 83-111.

Pagano, M., F. Panetta, and L. Zingales (1998), 'Why Do Companies Go Public? An Empirical Analysis', The Journal of Finance, Vol. 53, No. 1, pp. 27-64.

Pope, P. F., and S. McLeay (2011), 'The European IFRS Experiment: Objectives, Research Challenges and Some Early Evidence', Accounting and Business Research, Vol. 41, No. 3, pp. 233-266.

Rajan, R. G. and L. Zingales (1998), 'Which Capitalism? Lessons from the East Asian Crisis', Journal of Applied Corporate Finance, Vol. 11, No. 3, pp. 40-48.

Van Tendeloo, B., and A. Vanstraelen (2005), 'Earnings Management under German GAAP versus IFRS', European Accounting Review, Vol. 14, No. 1, pp. 155-180. 
APPENDIX
In order to construct our empirical metrics, we follow the methodology outlined in Barth et al. (2008). Earnings variability is measured as the variance of the residuals from the following regression ${ }^{21}$ :

$$
\begin{aligned}
\Delta N I_{i t}= & \alpha_{0}+\alpha_{1} \text { Size }_{i t}+\alpha_{2} \text { Sales growth }_{i t}+\alpha_{3} \text { Financial Leverage }_{i t}+\alpha_{4} \text { CF }_{i t} \\
& +\alpha_{5} \text { Big }_{i t}+\alpha_{6} \text { Foreign Sales }_{i t}+\sum \text { Industry Dummies }+\varepsilon_{i t}
\end{aligned}
$$

where $\Delta N I$ is the change in net income; Size is the natural logarithm of total assets; Sales growth is the actual growth in sales; Financial Leverage is end of year total liabilities divided by end of year equity book value; $C F$ is annual cash flow from operating activities divided by end of year total assets. We compute operating cash flows indirectly by subtracting accruals from net income before extraordinary items ${ }^{22}$; Big5 is an indicator variable that equals one if the firm is audited either by BDO, Deloitte, Ernst\&Young, KPMG, PriceWaterhouseCoopers or their predecessors, and zero otherwise; Foreign Sales is the percentage share of foreign sales. Using the residuals from this regression rather than the raw numbers mitigates the effects of differences in firm performance and financial statement verification (Big5). We acknowledge that to some degree the controls possibly capture reporting incentives. This could limit our ability to observe differences in earnings quality across different groups of firms.

Higher earnings variability might simply reflect higher volatility of the underlying cash flows rather than higher earnings quality. Therefore, our second earnings smoothing metric relates the variability of changes in net income to the variability of the changes in cash flows. It is computed as the ratio of standard deviation of the change in net income, $\Delta N I$, divided by

21 We also report results for empirical earnings quality proxies using raw values of input variables. A potential issue with the Barth et al. (2008) methodology is that the control variables, e.g., in equation (1), control for the level of changes in net income and not for their respective impact on the respective earnings quality proxy, i.e., variability in net income.

22 We compute accruals as ( $\Delta$ Total current assets $-\Delta$ Cash) $-\Delta$ Accounts payable $-\Delta$ Other current liabilities Depreciation. 
the standard deviation of the change in operating cash flows, $\triangle C F$. Again, we obtain the residuals from the following regression:

$$
\begin{aligned}
\Delta C F_{i t}= & \alpha_{0}+\alpha_{1} \text { Size }_{i t}+\alpha_{2} \text { Sales growth }_{i t}+\alpha_{3} \text { Financial Leverage }_{i t}+\alpha_{4} \text { CF }_{i t} \\
& +\alpha_{5} \text { Big }_{i t}+\alpha_{6} \text { Foreign Sales }_{i t}+\sum \text { Industry Dummies }+\varepsilon_{i t}
\end{aligned}
$$

Our third earnings smoothing measure is the contemporaneous Spearman correlation between accruals, $A C C$, and cash flows from operating activities, $C F$. We apply the same procedure as above, and compare the correlations of the residuals obtained from the following regressions:

$$
\begin{aligned}
\text { CF }_{i t}= & \alpha_{0}+\alpha_{1} \text { Size }_{i t}+\alpha_{2} \text { Sales growt }_{i t}+\alpha_{3} \text { Financial Leverage }_{i t}+ \\
& +\alpha_{4}{\text { Big } 5_{i t}+} \alpha_{5} \text { Foreign Sales }_{i t}+\sum \text { Industry Dummies }+\varepsilon_{i t} \\
\text { ACC }_{i t}= & \alpha_{0}+\alpha_{1} \text { Size }_{i t}+\alpha_{2} \text { Sales growt }_{i t}+\alpha_{3} \text { Financial Leverage }_{i t}+\alpha_{4} \text { CF }_{i t} \\
& +\alpha_{5}{\text { Big } 5_{i t}+}_{i t} \alpha_{6} \text { Foreign Sales }_{i t}+\sum \text { Industry Dummies }+\varepsilon_{i t}
\end{aligned}
$$

Our measure of managing earnings towards a target, i.e., small positive earnings, is captured by the coefficient on small positive net income, SPOS, in the following regression (Barth et al. 2008):

$$
\begin{aligned}
\operatorname{IFRS}(0,1)_{i t} \operatorname{POST}(0,1)_{i t} & =\alpha_{0}+\alpha_{1} \text { SPOS }_{i t}+\alpha_{2} \text { Size }_{i t}+\alpha_{3} \text { Sales growth }_{i t} \\
+ & \alpha_{4} \text { Financial Leverage }_{i t}+\alpha_{5} \text { CF }_{i t}+\alpha_{6} \text { Big }_{i t}+ \\
+ & \alpha_{7} \text { Foreign Sales }_{i t}+\sum \text { Industry Dummies }+\varepsilon_{i t}
\end{aligned}
$$

and a "reverse" specification:

$$
\begin{aligned}
\text { SPOS }_{i t}= & \alpha_{0}+\alpha_{1} \operatorname{IFRS}(0,1)_{i t} / \text { POST }(0,1)_{i t}+\alpha_{2} \text { Size }_{i t}+\alpha_{3} \text { Sales growth }_{i t} \\
& +\alpha_{4} \text { Financial Leverage }_{i t}+\alpha_{5} \text { CF }_{i t}+\alpha_{6} \text { Big }_{i t}+\alpha_{7} \text { Foreign Sales }_{i t}+ \\
& +\sum \text { Industry Dummies }+\varepsilon_{i t}
\end{aligned}
$$

where $\operatorname{IFRS}(0,1)$ is an indicator variable that equals one for IFRS firms and zero otherwise. $\operatorname{POST}(0,1)$ is an indicator variable that equals one (zero) for IFRS firms for the post-adoption 
(pre-adoption) period. SPOS is an indicator variable that equals one if net income scaled by total assets is between 0 and 0.01 . When we compare IFRS firms (using post-adoption observations) with German GAAP firms, $\operatorname{IFRS}(0,1)$ is the dependent variable. In this analysis, a negative coefficient on SPOS indicates that German GAAP firms manage toward small positive profits more frequently than IFRS firms. For the pre- and post-analysis of IFRS firms we use $\operatorname{POST}(0,1)$ as a dependent variable. In this case, a negative coefficient on SPOS indicates that IFRS firms manage earnings toward small positive profits less frequently in the post-adoption period than in the pre-adoption period. We also estimate the "reverse" specification (5b) where SPOS is the dependent variable, because it more directly captures the likelihood of the occurrence of small positive profits.

Finally, we measure timely loss recognition as the coefficient on large negative net income, $L N E G$, in the following regression (Barth et al. 2008):

$$
\begin{aligned}
\operatorname{IFRS}(0,1)_{i t} \operatorname{POST}(0,1)_{i t} & =\alpha_{0}+\alpha_{1} \text { LNEG }_{i t}+\alpha_{2} \text { Size }_{i t}+\alpha_{3} \text { Sales growth }_{i t} \\
+ & \alpha_{4} \text { Financial Leverage }_{i t}+\alpha_{5} \text { CF }_{i t}+\alpha_{6} \text { Big }_{i t}+ \\
+ & \alpha_{7} \text { Foreign Sales }_{i t}+\sum \text { Industry Dummies }+\varepsilon_{i t}
\end{aligned}
$$

and a "reverse" specification:

$$
\begin{aligned}
\text { LNEG }_{i t}= & \alpha_{0}+\alpha_{1} \operatorname{IFRS}(0,1)_{i t} / \operatorname{POST}(0,1)_{i t}+\alpha_{2} \text { Size }_{i t}+\alpha_{3} \text { Sales growt }_{i t} \\
& +\alpha_{4} \text { Financial Leverage }_{i t}+\alpha_{5} C F_{i t}+\alpha_{6} \text { Big }_{i t}+\alpha_{7} \text { Foreign Sales }_{i t}+ \\
& +\sum \text { Industry Dummies }+\varepsilon_{i t}
\end{aligned}
$$

where $L N E G$ is an indicator variable that equals one for observations for which annual net income scaled by total assets is less than -0.20 and zero otherwise. When comparing IFRS firms with German GAAP firms (IFRS $(0,1)$ is the dependent variable), a positive coefficient on LNEG indicates that IFRS firms recognize large losses more frequently than German GAAP firms. When comparing the pre-adoption and post-adoption period of IFRS firms $(\operatorname{POST}(0,1)$ is the dependent variable), a positive coefficient then indicates that IFRS firms recognize large 
losses more frequently in the post-adoption period than in the pre-adoption period. Again, we also estimate the "reverse" specification (6b) where $L N E G$ is the dependent variable, because it more directly captures the likelihood of the occurrence of large losses.

Following Barth et al. (2008), we compare several earnings quality metrics across different firm partitions. We interpret differences in various summary statistics related to the accounting metrics between the samples of firms as evidence of differences in earnings quality. We test for differences in each income smoothing metric using a t-test based on the empirical distribution of differences. Specifically, we first randomly select firm observations with replacement that we assign to one or the other type of the firm, depending on the test. Then, we calculate the difference between the two types of firms for each metric. We obtain the empirical distribution of differences by repeating this procedure a 1,000 times. 


\section{FIGURE 1}

Changes in Firm Characteristics around IFRS Adoption

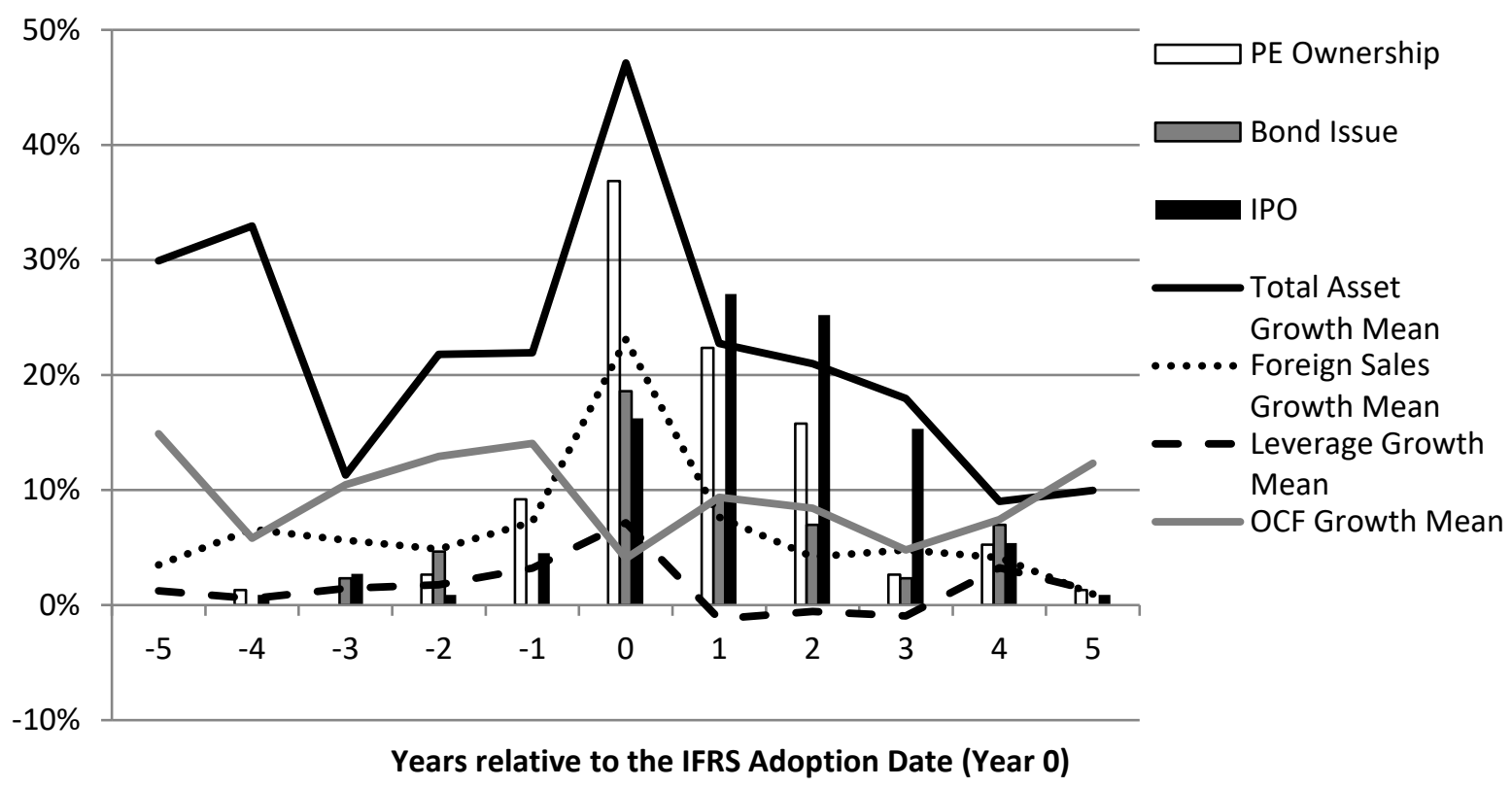

Notes: This figure shows the evolution of several key characteristics during a 10-year period around IFRS adoption dates (year 0). For the definition of variables, see Table 2. 
TABLE 1

Sample Selection Procedure

\begin{tabular}{|c|c|c|c|}
\hline \multirow[b]{2}{*}{ Sample selection and composition } & \multicolumn{3}{|c|}{ No. of firms } \\
\hline & Total & IFRS & German GAAP \\
\hline \multicolumn{4}{|l|}{ Firms on Hoppenstedt-Bilanzen that meet the following selection criteria: } \\
\hline $\begin{array}{l}\text { Equity shares are not listed on a stock exchange, non-financial firm, consolidated financial } \\
\text { statements in German GAAP or IFRS, and financial statement data available after } 1998\end{array}$ & 3,328 & 345 & 2,983 \\
\hline Less going-private firms & 251 & 157 & 94 \\
\hline Plus going-public (IPO) firms & 87 & 85 & 2 \\
\hline Initial sample & 3,164 & 273 & 2,891 \\
\hline No. of firms used in factor and cluster analyses (Table 2) & & 273 & - \\
\hline Max no. of firms used in earnings quality analyses (Table 4) & & 228 & 1,986 \\
\hline Max no. of firms used in disclosure analyses (Tables 6 to 9) & & 140 & 140 \\
\hline Distribution of observations across empirical analyses & \multicolumn{3}{|c|}{ No. of obs. } \\
\hline Earnings quality sample & Total & IFRS & German GAAP \\
\hline \multicolumn{4}{|l|}{ Table 4 sample - Earnings quality } \\
\hline Panel A - Post-adoption period & 10,281 & 784 & 9,497 \\
\hline Panel B - Pre- and Post-adoption period & 719 & 719 & - \\
\hline \multicolumn{4}{|l|}{ Table 5 sample - Earnings quality (Propensity score method) } \\
\hline Panel A - Post adoption period & 1,018 & 509 & 509 \\
\hline Panel B - Pre- and Post-adoption period & 856 & 428 & 428 \\
\hline Panel C - DID analyses & 856 & 428 & 428 \\
\hline \multicolumn{4}{|l|}{ Disclosure quality sample } \\
\hline Table 7 sample - Disclosure practices (Post-adoption period) & 711 & 362 & 349 \\
\hline Table 8 sample - Disclosure practices (DID analyses) & 178 & 108 & 70 \\
\hline Table 9 sample - Disclosure channel & 664 & 328 & 336 \\
\hline
\end{tabular}

Notes: This table reports the sample selection procedure. To investigate the reporting choices of private parent firms in their consolidated financial statements, we search the August 2011 version of Hoppenstedt-Bilanzen. Information on firms that went private before August 2011 is retrieved from Hoppenstedt-Aktienführer and the website of the German Association of Investors (Schutzgemeinschaft der Kapitalanleger, sdk.org). Going-public (IPO) firms are non-financial parent firms that went public on a regulated German stock exchange in the period from 2001 to October 2010. IPO data are obtained from the website of the Deutsche Börse Group (deutscheboerse.com). Going-private and going-public firms are classified as German GAAP or IFRS firm depending on the set of accounting standards applied in the going-private year and IPO year, respectively. To collect information on firms' IFRS switch years and ownership structure in the IFRS adoption year, we use various data sources including the "Wer gehört zu wem?" database of the Commerzbank AG, Hoppenstedt-Bilanzen, firms' annual reports and an extensive web search.

Depending on data availability, the number of observations can vary across our empirical tests. We attempt to use the maximum number of observations available per empirical test. To provide full transparency, we indicate which sample is used in the different analyses presented in subsequent tables. Table 4 Panel A compares the earnings quality of different types of IFRS adopting private firms in the post-adoption period with the average earnings quality of a comprehensive sample of German GAAP firms over the sample period. Table 4 Panel B examines changes in earnings quality measures for the different IFRS adopting firm types from the pre- to post-adoption period. Table 5 compares earnings quality for a propensity score-matched sample of German GAAP and IFRS firms in the post-adoption period (Panel A), changes in earnings quality from the pre- to post-adoption period (Panel B), and using a differences-in-differences design (Panel C). Table 7 examines disclosure practices a propensity score-matched sample of German GAAP and IFRS firms in the post-adoption period. Table 8 examines the disclosure practices for German GAAP and IFRS firms in the pre-and post-adoption period. Table 9 analyzes the disclosure channels for German GAAP and IFRS firms in the post-adoption period. 
TABLE 2

Factor Analysis and Cluster Analysis of IFRS Adopting Firm Characteristics

Panel A: Factor Analysis

Variable

Size

Sales Growth

Leverage

Return on Assets

$-0.4874$

Foreign Sales

Big5

Stock Corporation

0.3424

IPO

0.7238

Rating

Bonds

0.6995

Profit Participation Certificates

PE Ownership

0.4823

Medium and High Tech Industry

0.3730

Age

$-0.4193$

Panel B: Factor Scores and Firm Characteristics by Clusters

EQUITY

DEBT FINCON-PE REPUTATION Average

Factor scores

Equity market orientation

Debt market orientation

Financial condition

International activity

0.98

$-0.21$

$-0.46$

$-0.61$

$-0.28$

1.92

$-0.26$

$-0.28$

$-0.15$

0.04

$-0.43$

$-0.05$

0.20

$-0.16$

0.07

Firm characteristics

Size

$\begin{array}{ll}4.25 & 7.55 \\ 0.56 & 0.24\end{array}$

Sales Growth

Leverage

Return on Assets

$0.05 \quad 0.04$

0.86

$0.65 \quad 0.69$

Foreign Sales

39.78

50.58

$-0.01$

$0.07 \quad 0.04$

Big5

Stock Corporation

30.49

$42.18 \quad 39.90$

Medium and High Tech Industry

Age

IPO

Rating

Bonds

Profit Participation Certificates

0.09

0.02

PE Ownership 
TABLE 2 (continued)

Panel C: Distribution of IFRS Post-Adoption Firm-year Observations

\begin{tabular}{|c|c|c|c|c|c|c|c|c|c|c|c|c|c|c|c|}
\hline & \multicolumn{3}{|c|}{ All IFRS firms } & \multicolumn{3}{|c|}{ EQUITY firms } & \multicolumn{3}{|c|}{ DEBT firms } & \multicolumn{3}{|c|}{ PE firms } & \multicolumn{3}{|c|}{ REPUTATION firms } \\
\hline & $\mathrm{N}$ & $\%$ & Cum. \% & $\mathrm{N}$ & $\%$ & Cum. \% & $\mathrm{N}$ & $\%$ & Cum. \% & $\mathrm{N}$ & $\%$ & Cum. \% & $\mathrm{N}$ & $\%$ & Cum. \% \\
\hline 1999 & 5 & 0.64 & 0.64 & 5 & 1.69 & 1.69 & 0 & 0.00 & 0.00 & 0 & 0.00 & 0.00 & 0 & 0.00 & 0.00 \\
\hline 2000 & 12 & 1.53 & 2.17 & 11 & 3.72 & 5.41 & 0 & 0.00 & 0.00 & 1 & 0.98 & 0.98 & 0 & 0.00 & 0.00 \\
\hline 2001 & 14 & 1.79 & 3.95 & 11 & 3.72 & 9.12 & 2 & 1.28 & 1.28 & 1 & 0.98 & 1.96 & 0 & 0.00 & 0.00 \\
\hline 2002 & 19 & 2.42 & 6.38 & 12 & 4.05 & 13.18 & 4 & 2.56 & 3.85 & 1 & 0.98 & 2.94 & 2 & 0.87 & 0.87 \\
\hline 2003 & 22 & 2.81 & 9.18 & 12 & 4.05 & 17.23 & 6 & 3.85 & 7.69 & 1 & 0.98 & 3.92 & 3 & 1.3 & 2.17 \\
\hline 2004 & 39 & 4.97 & 14.16 & 22 & 7.43 & 24.66 & 9 & 5.77 & 13.46 & 1 & 0.98 & 4.9 & 7 & 3.04 & 5.22 \\
\hline 2005 & 57 & 7.27 & 21.43 & 30 & 10.14 & 34.8 & 15 & 9.62 & 23.08 & 3 & 2.94 & 7.84 & 9 & 3.91 & 9.13 \\
\hline 2006 & 110 & 14.03 & 35.46 & 47 & 15.88 & 50.68 & 22 & 14.1 & 37.18 & 11 & 10.78 & 18.63 & 30 & 13.04 & 22.17 \\
\hline 2007 & 144 & 18.37 & 53.83 & 57 & 19.26 & 69.93 & 24 & 15.38 & 52.56 & 17 & 16.67 & 35.29 & 46 & 20 & 42.17 \\
\hline 2008 & 174 & 22.19 & 76.02 & 53 & 17.91 & 87.84 & 31 & 19.87 & 72.44 & 29 & 28.43 & 63.73 & 61 & 26.52 & 68.7 \\
\hline 2009 & 145 & 18.49 & 94.52 & 31 & 10.47 & 98.31 & 28 & 17.95 & 90.38 & 29 & 28.43 & 92.16 & 57 & 24.78 & 93.48 \\
\hline 2010 & 43 & 5.48 & 100.00 & 5 & 1.69 & 100.00 & 15 & 9.62 & 100.00 & 8 & 7.84 & 100.00 & 15 & 6.52 & 100.00 \\
\hline Total & 784 & 100.00 & & 296 & 37.76 & & 156 & 19.90 & & 102 & 13.01 & & 230 & 29.34 & \\
\hline
\end{tabular}

Notes: This table presents results for our factor analysis (Panel A) and cluster analysis (Panel B) that are used to identify different types of IFRS adopting firms. Panel C shows the distribution of post-adoption firm-years by different types of IFRS adopting firms. EQUITY labels young, fast growing equity market oriented firms. DEBT denotes large, mature debt market oriented firms. FINCON-PEs are firms with a weak financial condition that in most cases are owned by a private equity sponsor. REPUTATION labels mature, highly profitable firms with substantial international activities. Size = natural logarithm of total assets; Leverage $=$ ratio of total liabilities to total assets; Foreign Sales = fraction of sales generated outside of Germany; Big5 = dummy variable taking the value one if a firm is audited by a Big5 audit company, and zero otherwise. Big5 auditors are BDO, Deloitte, Ernst\&Young, KPMG, PriceWaterhouseCoopers and their predecessors. Stock Corporation = dummy variable taking the value one if a firm is registered as a stock corporation, and zero otherwise; Medium and High Tech Industry = dummy variable taking the value one if a firm operates in a medium or high tech industry, and zero otherwise; Age is the years since foundation of the firm (Source: Hoppenstedt-Bilanzen); IPO = dummy variable taking the value one if a firm plans an IPO, cancels an IPO, or completes an IPO between 2001 and 2010, or will do so during the next three years. Otherwise, the dummy variable is zero. Data on planned IPOs are gathered from IPO surveys published by GoingPublic Magazin and German Private Equity and Venture Capital Association (Bundesverband Deutscher Kapitalbeteiligungsgesellschaften e. V. (BVK)) and an extensive web search; data on cancelled IPOs are gathered (1) by matching lists on IPOs planned and IPOs completed and (2) a supplemental web search; data on completed IPOs between 2001 and October 2010 are obtained from the website of the Deutsche Börse Group (deutsche-boerse.com); Rating = dummy variable taking the value one if a firm has a rating; Bonds (Profit Participation Certificates) = dummy variable taking the value one if a firm has a bond outstanding (has a profit participation right outstanding) or will do so during the future three years. Otherwise, the dummy variable is zero. Data on bonds and profit participation rights (PPC) are taken from Datastream; PE Ownership = dummy variable taking the value one if a firm is controlled by private equity investors, and zero otherwise. Data on private equity investments in Germany are collected from 2005 to 2010 and obtained from Majunke Consulting. 
TABLE 3

Descriptive Statistics Relating to Variables Used in Earnings Quality Analyses

Panel A: Descriptive statistics for the full sample

\begin{tabular}{|c|c|c|c|c|c|c|c|c|}
\hline & \multicolumn{4}{|c|}{ IFRS } & \multicolumn{4}{|c|}{ German GAAP } \\
\hline & $\mathrm{N}$ & Mean & Median & $\mathrm{SD}$ & $\mathrm{N}$ & Mean & Median & SD \\
\hline \multicolumn{9}{|l|}{ Test variables } \\
\hline$\Delta \mathrm{NI}$ & 1,168 & 0.01 & 0.01 & 0.07 & 9,497 & $0.00 * *$ & $0.00 * * *$ & 0.06 \\
\hline$\Delta \mathrm{CF}$ & 867 & 0.01 & 0.02 & 0.21 & 7,170 & 0.00 & 0.00 & 0.17 \\
\hline $\mathrm{ACC}$ & 1,168 & -0.03 & -0.04 & 0.19 & 9,497 & $-0.05 * * *$ & $-0.05 * * *$ & 0.13 \\
\hline $\mathrm{CF}$ & 1,168 & 0.10 & 0.10 & 0.21 & 9,497 & $0.11 * * *$ & $0.10^{*}$ & 0.16 \\
\hline SPOS & 1,168 & 0.06 & 0.00 & 0.24 & 9,497 & $0.10 * * *$ & $0.00 * * *$ & 0.31 \\
\hline LNEG & 1,168 & 0.03 & 0.00 & 0.18 & 9,497 & $0.00 * * *$ & $0.00 * * *$ & 0.09 \\
\hline \multicolumn{9}{|l|}{ Incentive and Control variables } \\
\hline Size & 1,168 & 19.82 & 19.91 & 1.94 & 9,497 & $18.87 * * *$ & $18.71 * *$ & 1.28 \\
\hline Leverage & 1,168 & 0.67 & 0.70 & 0.20 & 9,497 & 0.66 & $0.68 * * *$ & 0.19 \\
\hline Sales Growth & 1,158 & 0.24 & 0.08 & 0.56 & 9,494 & $0.12 * * *$ & $0.04 * * *$ & 0.37 \\
\hline Foreign Sales & 1,168 & 45.14 & 48.00 & 34.04 & 9,497 & $21.73 * * *$ & $3.00 * * *$ & 27.53 \\
\hline Big5 & 1,168 & 0.72 & 1.00 & 0.45 & 9,497 & $0.46^{* * * *}$ & $0.00 * * *$ & 0.50 \\
\hline Stock Corporation & 1,168 & 0.63 & 1.00 & 0.48 & 9,497 & $0.19 * * *$ & $0.00 * * *$ & 0.39 \\
\hline Medium and High Tech Industry & 1,168 & 0.34 & 0.00 & 0.47 & 9,497 & $0.12 * * *$ & $0.00 * * *$ & 0.33 \\
\hline Age & 1,160 & 49.39 & 25.00 & 54.25 & 7,157 & 49.44 & $32.00 * * *$ & 49.98 \\
\hline IPO & 1,168 & 0.43 & 0.00 & 0.50 & 9,497 & $0.00 * * *$ & $0.00 * * *$ & 0.06 \\
\hline Rating & 1,168 & 0.17 & 0.00 & 0.38 & 9,497 & $0.01 * * *$ & $0.00 * * *$ & 0.10 \\
\hline Bonds & 1,168 & 0.21 & 0.00 & 0.41 & 9,497 & $0.01 * * *$ & $0.00 * * *$ & 0.07 \\
\hline Profit Participation Certificates & 1,168 & 0.04 & 0.00 & 0.18 & 9,497 & $0.00 * * *$ & $0.00 * * *$ & 0.06 \\
\hline PE Ownership & 1,168 & 0.32 & 0.00 & 0.47 & 9,497 & $0.03 * * *$ & $0.00 * * *$ & 0.18 \\
\hline
\end{tabular}


TABLE 3 (continued)

Panel B: Descriptive statistics for the propensity score-matched sample

\begin{tabular}{|c|c|c|c|c|c|c|c|c|}
\hline & \multicolumn{4}{|c|}{ IFRS } & \multicolumn{4}{|c|}{ German GAAP } \\
\hline & $\mathrm{N}$ & Mean & Median & SD & $\mathrm{N}$ & Mean & Median & SD \\
\hline \multicolumn{9}{|l|}{ Test variables } \\
\hline$\Delta \mathrm{NI}$ & 755 & 0.01 & 0.01 & 0.06 & 755 & $0.00 * * *$ & $0.00 * *$ & 0.06 \\
\hline$\Delta \mathrm{CF}$ & 500 & 0.01 & 0.01 & 0.21 & 500 & 0.01 & 0.01 & 0.17 \\
\hline $\mathrm{ACC}$ & 755 & -0.04 & -0.05 & 0.19 & 755 & $-0.05^{*}$ & -0.05 & 0.14 \\
\hline $\mathrm{CF}$ & 755 & 0.11 & 0.10 & 0.20 & 755 & 0.11 & $0.11 *$ & 0.15 \\
\hline SPOS & 755 & 0.06 & 0.00 & 0.23 & 755 & $0.11 * * *$ & $0.00 * *$ & 0.31 \\
\hline LNEG & 755 & 0.02 & 0.00 & 0.13 & 755 & $0.01 * * *$ & $0.00^{*}$ & 0.11 \\
\hline \multicolumn{9}{|l|}{ Incentive and Control variables } \\
\hline Size & 755 & 20.05 & 20.11 & 1.93 & 755 & 20.18 & 19.79 & 1.88 \\
\hline Leverage & 755 & 0.67 & 0.70 & 0.19 & 755 & $0.72 * * *$ & $0.71 * * *$ & 0.19 \\
\hline Sales Growth & 751 & 0.24 & 0.09 & 0.54 & 755 & $0.13 * * *$ & $0.05 * * *$ & 0.42 \\
\hline Foreign Sales & 755 & 44.36 & 47.00 & 34.16 & 755 & $40.64 * *$ & $42.00 * *$ & 34.30 \\
\hline Big5 & 755 & 0.74 & 1.00 & 0.44 & 755 & $0.64 * * *$ & $1.00 * * *$ & 0.48 \\
\hline Stock Corporation & 755 & 0.58 & 1.00 & 0.49 & 755 & $0.52 * *$ & $1.00 * *$ & 0.50 \\
\hline Medium and High Tech Industry & 755 & 0.30 & 0.00 & 0.46 & 755 & $0.19 * * *$ & $0.00 * * *$ & 0.39 \\
\hline Age & 755 & 49.50 & 25.00 & 53.94 & 755 & $55.24 * *$ & $32.00 * * *$ & 52.75 \\
\hline IPO & 755 & 0.37 & 0.00 & 0.48 & 755 & $0.05^{* * *}$ & $0.00 * * *$ & 0.22 \\
\hline Rating & 755 & 0.22 & 0.00 & 0.42 & 755 & $0.01 * * *$ & $0.00 * * *$ & 0.08 \\
\hline Bonds & 755 & 0.23 & 0.00 & 0.42 & 755 & $0.00 * * *$ & $0.00 * * *$ & 0.05 \\
\hline Profit Participation Certificates & 755 & 0.03 & 0.00 & 0.16 & 755 & $0.00 * * *$ & $0.00 * * *$ & 0.05 \\
\hline PE Ownership & 755 & 0.31 & 0.00 & 0.46 & 755 & $0.06^{* * *}$ & $0.00 * * *$ & 0.23 \\
\hline
\end{tabular}

Notes: This table presents descriptive statistics on the variables used in the empirical analyses of earnings quality. Panel A shows descriptive statistics for the full sample used in Table 4, Panel B for the propensity score-matched sample used in Table 5. Financial statement data are retrieved from Hoppenstedt-Bilanzen. N indicates the number of firm-year observations. Test variables: $\Delta \mathrm{NI}=$ change in net income; $\Delta \mathrm{CF}=$ change in cash flow from operations; $\mathrm{ACC}=$ accruals $; \mathrm{CF}=$ annual cash flow from operating activities divided by end of year total assets; SPOS = indicator variable that equals one if net income scaled by total assets is between 0 and 0.01 ; LNEG $=$ indicator variable that equals one for observations for which annual net income scaled by total assets is less than -0.20 and zero otherwise. Incentive and control variables are defined in Table 2. Continuous variables are winsorized at the one percent level in both tails of the distribution. Mean (median) differences between IFRS and German GAAP firms are tested by applying a two-sided t-test (Wilcoxon rank-sum test): * $\mathrm{p}<0.10, * * \mathrm{p}<0.05, * * * \mathrm{p}<0.01$. 
TABLE 4

IFRS and Earnings Quality by Type of IFRS Adopting Firms

Panel A: Post-adoption period

\begin{tabular}{|c|c|c|c|c|c|c|c|c|}
\hline Variability of $\triangle N I^{*}(\Delta N I)$ & EQUITY (1) & DEBT (2) & FINCON-PE (3) & REPUT. (4) & (1)-(2) & \multirow{6}{*}{$\begin{array}{l}(3)-(1) \\
-0.0021 \\
\left(-0.0037^{* * *}\right)\end{array}$} & \multirow{6}{*}{$\begin{array}{l}(3)-(4) \\
0.0028^{* * *} \\
\left(0.0021^{* *}\right)\end{array}$} & \multirow{6}{*}{$\begin{array}{l}(4)-(2) \\
0.0021^{* * *} \\
\left(0.0021^{* * *}\right)\end{array}$} \\
\hline IFRS (a) & $0.0085(0.0095)$ & $0.0014(0.0015)$ & $0.0064(0.0057)$ & $0.0035(0.0036)$ & \multirow{5}{*}{$\begin{array}{l}0.0071 * * * \\
(0.0080 * * *)\end{array}$} & & & \\
\hline $\mathrm{N}$ & $293(296)$ & $156(156)$ & $102(102)$ & $229(230)$ & & & & \\
\hline German GAAP (b) & & & & & \\
\hline $\mathrm{N}$ & \multicolumn{4}{|c|}{$9,270(9,497)$} & & & & \\
\hline Difference (a) - (b) & $0.0050^{* * *}\left(0.0058^{* * *}\right)$ & $-0.0021^{* * *}\left(-0.0022^{* * * *}\right)$ & $0.0029 * * * *(0.0021)$ & $0.0001(-0.0001)$ & & & & \\
\hline Variability of $\triangle N I^{*}(\triangle N I)$ over $\triangle C F^{*}(\triangle C F)$ & EQUITY (1) & DEBT (2) & FINCON-PE (3) & REPUT. (4) & \multirow{6}{*}{$\begin{array}{l}(1)-(2) \\
0.3374 * * * \\
\left(0.2756^{* * *}\right)\end{array}$} & \multirow{6}{*}{$\begin{array}{l}(3)-(1) \\
-0.0725 \\
(-0.1871)\end{array}$} & \multirow{6}{*}{$\begin{array}{l}(3)-(4) \\
-0.0163 \\
(0.0419)\end{array}$} & \multirow{6}{*}{$\begin{array}{l}(4)-(2) \\
0.2813^{* * * *} \\
\left(0.1452^{* * *}\right)\end{array}$} \\
\hline IFRS (a) & $0.7535(0.5968)$ & $0.4146(0.3212)$ & $0.6807(0.5083)$ & $0.6979(0.4664)$ & & & & \\
\hline $\mathrm{N}$ & $276(276)$ & $139(139)$ & $73(73)$ & $189(189)$ & & & & \\
\hline German GAAP (b) & \multirow{2}{*}{\multicolumn{4}{|c|}{$\begin{array}{c}0.6485(0.4473) \\
8,144(8,300)\end{array}$}} & & & & \\
\hline $\mathrm{N}$ & & & & & & & & \\
\hline Difference (a) - (b) & $0.1050^{* * *}(0.1495 * * *)$ & $-0.2323^{* * *}\left(-0.1261^{* * * *}\right)$ & $0.0326(0.0610)$ & $0.0489(0.0191)$ & & & & \\
\hline Correlation of $A C C^{*}(A C C)$ and $C F^{*}(C F)$ & EQUITY (1) & DEBT (2) & FINCON-PE (3) & REPUT. (4) & \multirow{6}{*}{$\begin{array}{l}(1)-(2) \\
0.0539 \\
(0.0420)\end{array}$} & \multirow{6}{*}{$\begin{array}{l}(3)-(1) \\
-0.0509 \\
(-0.0387)\end{array}$} & \multirow{6}{*}{$\begin{array}{l}(3)-(4) \\
-0.0195 \\
(-0.0291)\end{array}$} & \multirow{6}{*}{$\begin{array}{l}(4)-(2) \\
0.0225 \\
(-0.0096)\end{array}$} \\
\hline IFRS (a) & $-0.6956(-0.6822)$ & $-0.7535(-0.7241)$ & $-0.7465(-0.7629)$ & $-0.7259(-0.7338)$ & & & & \\
\hline $\mathrm{N}$ & $292(292)$ & $156(156)$ & $101(102)$ & $228(229)$ & & & & \\
\hline German GAAP (b) & \multirow{2}{*}{\multicolumn{4}{|c|}{$\begin{array}{c}-0.7509(-0.7481) \\
9,153(9,414)\end{array}$}} & & & & \\
\hline $\mathrm{N}$ & & & & & & & & \\
\hline Difference (a) - (b) & $0.0554 * *(0.0659 * * *)$ & $-0.0026(0.024)$ & $0.0440(-0.0147)$ & $0.0250(0.0144)$ & & & & \\
\hline Small positive NI (SPOS) & EQUITY (1) & DEBT (2) & FINCON-PE (3) & REPUT. (4) & \multirow{5}{*}{$\begin{array}{l}(1)-(2) \\
0.0084\end{array}$} & \multirow{5}{*}{$\begin{array}{l}(3)-(1) \\
0.0061\end{array}$} & \multirow{5}{*}{$\begin{array}{l}(3)-(4) \\
0.0149 * * *\end{array}$} & \multirow{5}{*}{$\begin{array}{l}(4)-(2) \\
-0.0004\end{array}$} \\
\hline Coefficient & $-0.0066^{*}$ & $-0.0171 * * *$ & -0.0051 & $-0.0161 * * *$ & & & & \\
\hline Coefficient-Reverse Reg. & $-0.0237 *$ & $-0.0966 * * *$ & -0.0397 & $-0.0611 * * *$ & & & & \\
\hline $\mathrm{N}$ & 9,649 & 9,510 & 9,460 & 9,589 & & & & \\
\hline N IFRS Observations & 295 & 156 & 106 & 235 & & & & \\
\hline Large negative NI (LNEG) & EQUITY (1) & $\operatorname{DEBT}(2)$ & FINCON-PE (3) & REPUT. (4) & \multirow{5}{*}{$\begin{array}{l}(1)-(2) \\
0.2823^{* * *}\end{array}$} & \multirow{5}{*}{$\begin{array}{l}(3)-(1) \\
-0.2547 * * *\end{array}$} & \multirow{5}{*}{$\begin{array}{l}(3)-(4) \\
0.0319\end{array}$} & \multirow{5}{*}{$\begin{array}{l}(4)-(2) \\
-0.0044\end{array}$} \\
\hline Coefficient & $0.2834 * * *$ & 0.0077 & 0.0352 & 0.0004 & & & & \\
\hline Coefficient - Reverse Reg. & $0.0965^{* * *}$ & $0.0056^{* *}$ & 0.0212 & 0.0014 & & & & \\
\hline $\mathrm{N}$ & 9,649 & 9,510 & 9,460 & 9,589 & & & & \\
\hline N IFRS Observations & 295 & 156 & 106 & 235 & & & & \\
\hline
\end{tabular}


Panel B: Change in Earnings Quality around IFRS adoptions by Type of Firms

\begin{tabular}{|c|c|c|c|c|c|c|}
\hline EQUITY & Pre Obs. & Post Obs. & Pre (1) & Post (2) & Exp. Sign & Diff. (2) - (1) \\
\hline Variability of $\Delta \mathrm{NI}^{*}$ & 53 & 51 & 0.0039 & 0.0081 & + & $0.0043^{* * *}$ \\
\hline Variability of $\Delta \mathrm{NI}$ & 53 & 51 & 0.0049 & 0.0075 & + & $0.0026^{*}$ \\
\hline Variability of $\Delta \mathrm{NI}^{*}$ over $\Delta \mathrm{CF}^{*}$ & 45 & 44 & 0.5963 & 1.1403 & + & $0.5440 * * *$ \\
\hline Variability of $\Delta \mathrm{NI}$ over $\Delta \mathrm{CF}$ & 45 & 44 & 0.4717 & 0.9316 & + & $0.4599 * * *$ \\
\hline Correlation of $\mathrm{ACC}^{*}$ and $\mathrm{CF}^{*}$ & 53 & 51 & -0.7085 & -0.5728 & + & 0.1356 \\
\hline \multirow[t]{2}{*}{ Correlation of ACC and CF } & 53 & 48 & -0.6630 & -0.6232 & + & 0.0397 \\
\hline & Obs. & & Coefficient & & Exp. Sign & Significance \\
\hline Small positive NI (SPOS) & & 109 & -0.0243 & & - & No \\
\hline Large negative NI (LNEG) & & 109 & 0.2425 & & + & No \\
\hline
\end{tabular}

\begin{tabular}{|c|c|c|c|c|c|c|}
\hline DEB T & Pre Obs. & Post Obs. & Pre (1) & Post (2) & Exp. Sign & Diff. (2) - (1) \\
\hline Variability of $\Delta \mathrm{NI}^{*}$ & 83 & 99 & 0.0021 & 0.0016 & + & -0.0005 \\
\hline Variability of $\Delta \mathrm{NI}$ & 83 & 99 & 0.0025 & 0.0018 & + & -0.0007 \\
\hline Variability of $\Delta \mathrm{NI}^{*}$ over $\Delta \mathrm{CF}^{*}$ & 81 & 90 & 0.6092 & 0.4967 & + & -0.1126 \\
\hline Variability of $\Delta \mathrm{NI}$ over $\Delta \mathrm{CF}$ & 81 & 90 & 0.4166 & 0.3396 & + & -0.0770 \\
\hline Correlation of $\mathrm{ACC}^{*}$ and $\mathrm{CF}^{*}$ & 82 & 99 & -0.7902 & -0.7585 & + & 0.0317 \\
\hline Correlation of ACC and CF & 83 & 99 & -0.7171 & -0.7122 & + & 0.0048 \\
\hline
\end{tabular}

Small positive NI (SPOS)

Large negative NI (LNEG)

\begin{tabular}{cccc} 
Obs. & Coefficient & Exp. Sign & Significance \\
\hline 183 & -0.0753 & - & No \\
183 & - & + & -
\end{tabular}

\begin{tabular}{lrrrrrl} 
FINCON-PE & Pre Obs. & Post Obs. & Pre (1) & Post (2) & Exp. Sign & Diff. (2) - (1) \\
\hline Variability of $\Delta \mathrm{NI}^{*}$ & 42 & 34 & 0.0041 & 0.0035 & + & -0.0006 \\
Variability of $\Delta \mathrm{NI}$ & 44 & 34 & 0.0031 & 0.0037 & + & 0.0007 \\
Variability of $\Delta \mathrm{NI}^{*}$ over $\Delta \mathrm{CF}^{*}$ & 40 & 17 & 0.4155 & 0.2171 & + & $-0.1983^{* * *}$ \\
Variability of $\Delta \mathrm{NI}$ over $\Delta \mathrm{CF}$ & 40 & 17 & 0.2068 & 0.2189 & + & 0.0121 \\
Correlation of ACC* and $\mathrm{CF} *$ & 41 & 33 & -0.8157 & -0.6424 & + & 0.1732 \\
Correlation of ACC and $\mathrm{CF}$ & 44 & 34 & -0.8312 & -0.6971 & + & 0.1341
\end{tabular}

Small positive NI (SPOS)

Large negative NI (LNEG)

\begin{tabular}{clcc} 
Obs. & Coefficient & Exp. Sign & Significance \\
\hline 80 & 0.1562 & - & No \\
80 & - & + & -
\end{tabular}

\begin{tabular}{|c|c|c|c|c|c|c|}
\hline REPUTATION & Pre Obs. & Post Obs. & Pre (1) & Post (2) & Exp. Sign & Diff. (2) - (1) \\
\hline Variability of $\Delta \mathrm{NI}^{*}$ & 199 & 143 & 0.0027 & 0.0031 & + & 0.0004 \\
\hline Variability of $\Delta \mathrm{NI}$ & 202 & 143 & 0.0030 & 0.0032 & + & 0.0003 \\
\hline Variability of $\Delta \mathrm{NI}^{*}$ over $\Delta \mathrm{CF}^{*}$ & 178 & 121 & 0.4263 & 0.6880 & + & $0.2616^{* * *}$ \\
\hline Variability of $\Delta \mathrm{NI}$ over $\Delta \mathrm{CF}$ & 181 & 121 & 0.3679 & 0.5352 & + & $0.1673 * * *$ \\
\hline Correlation of $\mathrm{ACC}^{*}$ and $\mathrm{CF}^{*}$ & 195 & 142 & -0.8733 & -0.7635 & + & $0.1098 * * *$ \\
\hline \multirow[t]{2}{*}{ Correlation of ACC and CF } & 202 & 143 & -0.8509 & -0.7343 & + & $0.1166^{* * *}$ \\
\hline & \multicolumn{2}{|r|}{ Obs. } & \multicolumn{2}{|c|}{ Coefficient } & Exp. Sign & Significance \\
\hline Small positive NI (SPOS) & \multicolumn{2}{|r|}{347} & \multicolumn{2}{|l|}{-0.1788} & - & $* *$ \\
\hline Large negative NI (LNEG) & \multicolumn{2}{|r|}{347} & - & & + & - \\
\hline
\end{tabular}




\section{TABLE 4 (continued)}

Notes: Panel A presents results for several earnings quality measures for different types of IFRS adopting private firms in the post-adoption period and for a comprehensive sample of German GAAP firms whose earnings quality is measured using all available observations over the sample period. Panel B shows the changes in earnings quality measures for the different IFRS adopting firm types from the pre- to post-adoption period. IFRS adopting firm types are identified and defined in Table 2. $\triangle \mathrm{NI}^{*}, \Delta \mathrm{CF}^{*}, \mathrm{CF}^{*}$ and $\mathrm{ACC}^{*}$ are defined as the residuals from regressions of $\triangle \mathrm{NI}, \triangle \mathrm{CF}, \mathrm{CF}$ and $\mathrm{ACC}$, respectively, on the incentive and control variables (see Model 1 to Model 4 in the Appendix). $\triangle \mathrm{NI}, \triangle \mathrm{CF}, \mathrm{CF}, \mathrm{ACC}$ are defined in Table 3. Pre Obs. (Post Obs.) indicates firm-year observations before (after) IFRS adoption. *, **, *** indicates significantly different from zero at the $10 \%, 5 \%$, or $1 \%$ level (two-sided). 
TABLE 5

The Incremental Effect of IFRS on Earnings Quality

Panel A: Post-Adoption Analyses

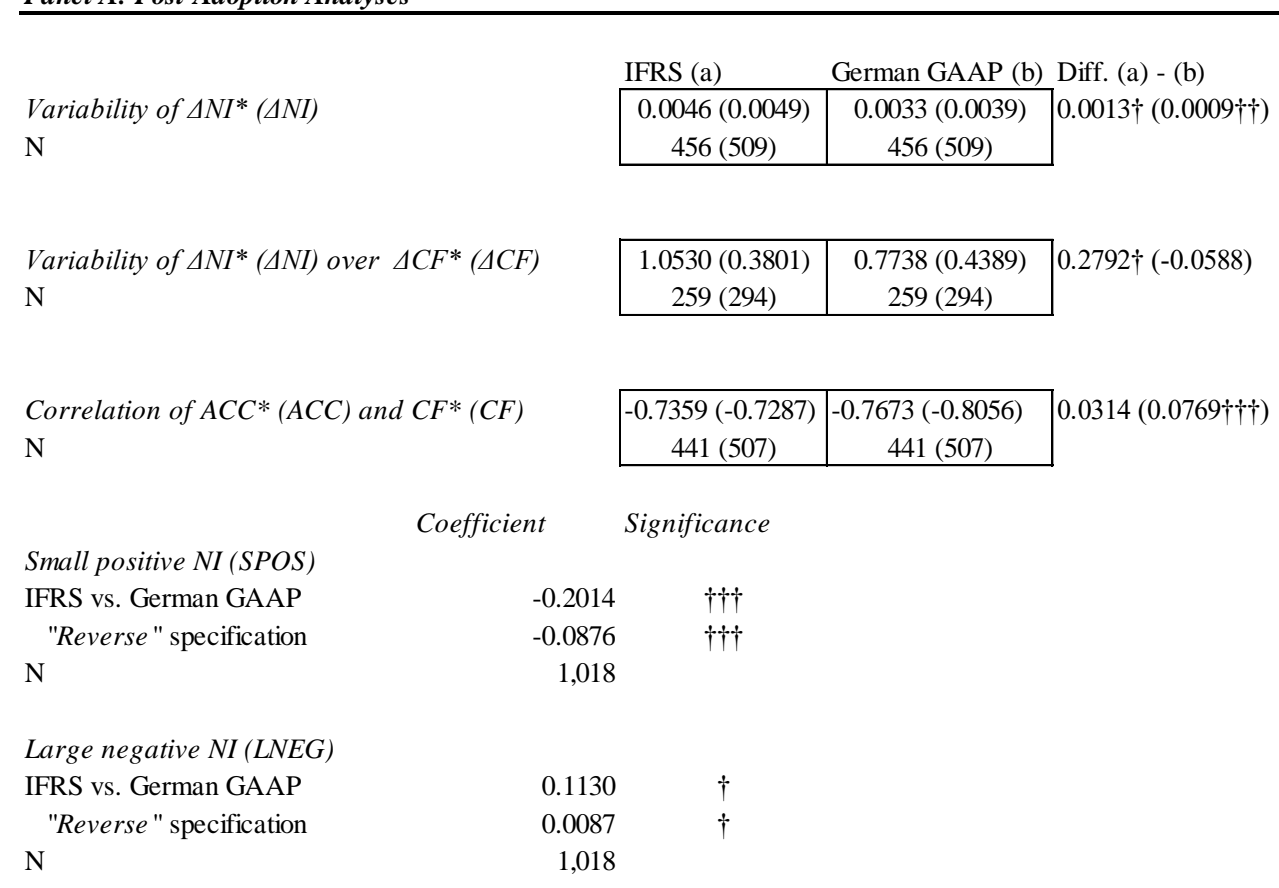

Panel B: Change in Earnings Quality around IFRS adoptions for IFRS and matched German GAAP firms

\begin{tabular}{|c|c|c|c|c|c|c|c|}
\hline & & Pre Obs. & Post Obs. & Pre (1) & Post (2) & Exp. Sign & Diff. (2) - (1) \\
\hline \multirow[t]{2}{*}{ Variability of $\triangle N I^{*}$} & IFRS & 192 & 236 & 0.0021 & 0.0038 & + & $0.0016 \dagger \dagger \dagger$ \\
\hline & German GAAP & 192 & 236 & 0.0020 & 0.0041 & $?$ & $0.0020+1 \dagger$ \\
\hline \multirow[t]{2}{*}{ Variability of $\triangle N I$} & IFRS & 194 & 236 & 0.0020 & 0.0039 & + & $0.0019+\dagger \dagger$ \\
\hline & German GAAP & 194 & 236 & 0.0027 & 0.0036 & $?$ & $0.0009 \dagger$ \\
\hline \multirow[t]{2}{*}{ Variability of $\triangle N I^{*}$ over $\triangle C F^{*}$} & IFRS & 139 & 129 & 0.4935 & 0.7668 & + & $0.2733+\dagger \dagger$ \\
\hline & German GAAP & 139 & 129 & 0.7777 & 0.8244 & $?$ & 0.0467 \\
\hline \multirow[t]{2}{*}{ Variability of $\triangle N I$ over $\triangle C F$} & IFRS & 139 & 129 & 0.3462 & 0.4378 & + & $0.0916 \dagger \dagger$ \\
\hline & German GAAP & 139 & 129 & 0.5204 & 0.4905 & $?$ & -0.0299 \\
\hline \multirow[t]{2}{*}{ Correlation of $A C C^{*}$ and $C F^{*}$} & IFRS & 191 & 233 & -0.8226 & -0.7174 & + & $0.1052 \dagger \dagger \dagger$ \\
\hline & German GAAP & 191 & 233 & -0.7998 & -0.7454 & $?$ & 0.0544 \\
\hline \multirow[t]{3}{*}{ Correlation of $A C C$ and $C F$} & IFRS & 194 & 234 & -0.7841 & -0.6911 & + & $0.0930 \dagger \dagger \dagger$ \\
\hline & German GAAP & 194 & 234 & -0.7973 & -0.7471 & $?$ & 0.0502 \\
\hline & & & Obs. & Coeff & ient & Exp. Sign & Significance \\
\hline \multirow[t]{2}{*}{ Small positive NI (SPOS) } & IFRS & & 458 & -0.0 & & - & No \\
\hline & German GAAP & & 458 & 0.0 & & $?$ & No \\
\hline \multirow[t]{2}{*}{ Large negative NI (LNEG) } & IFRS & & 458 & 0.5 & & + & t†t \\
\hline & German GAAP & & 458 & 0.16 & & + & $\dagger$ \\
\hline \multicolumn{8}{|l|}{ "Reverse" specification } \\
\hline \multirow[t]{2}{*}{ Small positive NI (SPOS) } & IFRS & & 458 & -0.0 & & - & No \\
\hline & German GAAP & & 458 & 0.00 & & $?$ & No \\
\hline \multirow[t]{2}{*}{ Large negative NI (LNEG) } & IFRS & & 458 & 0.0 & & + & $\dagger$ \\
\hline & German GAAP & & 458 & 0.00 & & + & No \\
\hline
\end{tabular}


TABLE 5 (continued)

Panel C: Differences-in-Differences in Earnings Quality Around IFRS Adoptions

\begin{tabular}{|c|c|c|c|c|}
\hline & \multirow[b]{2}{*}{ Prediction } & IAS & \multicolumn{2}{|c|}{ German GAAP } \\
\hline & & Post-Pre & Post-Pre & Difference \\
\hline Variability of $\triangle N I^{*}$ & IFRS $>$ German GAAP & 0.0016 & 0.0020 & -0.0004 \\
\hline Variability of $\triangle N I$ & IFRS $>$ German GAAP & 0.0019 & 0.0009 & 0.0010 \\
\hline Variability of $\triangle N I^{*}$ over $\triangle C F^{*}$ & IFRS $>$ German GAAP & 0.2733 & 0.0467 & 0.2267 \\
\hline Variability of $\triangle N I$ over $\triangle C F$ & IFRS $>$ German GAAP & 0.0916 & -0.0299 & $0.1214 \dagger$ \\
\hline Correlation of $A C C^{*}$ and $C F^{*}$ & IFRS $>$ German GAAP & 0.1052 & 0.0544 & 0.0508 \\
\hline Correlation of $A C C$ and $C F$ & IFRS $>$ German GAAP & 0.0930 & 0.0502 & 0.0427 \\
\hline Small positive NI (SPOS) & - & -0.0690 & 0.0135 & -0.0825 \\
\hline "Reverse" specification & - & -0.0170 & 0.0049 & -0.0218 \\
\hline Large negative NI (LNEG) & + & 0.5904 & 0.1654 & $0.4250 \uparrow \uparrow$ \\
\hline "Reverse" specification & + & 0.0100 & 0.0017 & 0.0083 \\
\hline
\end{tabular}

Notes: This table presents the results on differences in several earnings quality measures between propensity scorematched IFRS and German GAAP firms. $\triangle \mathrm{NI}^{*}, \triangle \mathrm{CF}^{*}, \mathrm{CF}^{*}$ and $\mathrm{ACC}^{*}$ are defined as the residuals from regressions of $\triangle \mathrm{NI}, \triangle \mathrm{CF}, \mathrm{CF}$ and ACC, respectively, on the incentive and control variables from Table 3. $\triangle \mathrm{NI}, \triangle \mathrm{CF}, \mathrm{CF}, \mathrm{ACC}$ are defined in Table 3. Panel A shows the results for the post-adoption period. Panel B shows the changes in earnings quality measures for the IFRS and matched German GAAP firms from the pre- to post-adoption period. Panel C compares the changes in earnings quality metrics for IFRS and German GAAP firms between the pre- and postadoption period (differences-in-differences test). For definition of earnings quality measures, see Table 3 . N indicates firm-year observations. $\uparrow, \uparrow \dagger, \uparrow \dagger \dagger$ indicates significantly different from zero at the $10 \%, 5 \%$, or $1 \%$ level (one-sided). 
TABLE 6

Descriptive Statistics of Disclosure Variables

\begin{tabular}{|c|c|c|c|c|c|c|c|c|c|c|}
\hline & \multicolumn{5}{|c|}{ IFRS } & \multicolumn{5}{|c|}{ German GAAP } \\
\hline & EQUITY & DEBT & FINCON-PE & REPUTATION & Total & EQUITY & DEBT & FINCON-PE & REPUTATION & Total \\
\hline \multicolumn{11}{|l|}{ Financial statement source } \\
\hline Website & $0.69 * * *$ & $0.83^{* * *}$ & 0.33 & $0.33^{* * *}$ & $0.56^{* * *}$ & 0.28 & 0.28 & 0.30 & 0.10 & 0.23 \\
\hline Bundesanzeiger & $0.31 * * *$ & $0.17 * * *$ & 0.67 & $0.67 * * *$ & $0.44^{* * *}$ & 0.72 & 0.72 & 0.70 & 0.90 & 0.77 \\
\hline \multicolumn{11}{|l|}{ Disclosure quantity } \\
\hline AR Pages & $77.58 * * *$ & $112.58 * * *$ & $54.85^{* *}$ & $65.92 * * *$ & $81.62 * * *$ & 32.46 & 36.39 & 37.98 & 22.83 & 31.43 \\
\hline MD\&A Pages & $17.69 * * *$ & $25.30 * * *$ & $10.63^{*}$ & $10.10^{* * *}$ & $16.34 * * *$ & 7.50 & 8.73 & 7.43 & 5.97 & 7.29 \\
\hline Notes Pages & $27.44 * * *$ & $36.14 * * *$ & $28.84 * * *$ & $31.63 * * *$ & $32.21 * * *$ & 6.79 & 8.19 & 7.88 & 6.68 & 7.30 \\
\hline Disclosure_Content1 & $6.14^{* * * *}$ & $5.11 * * *$ & $6.03 * * *$ & $5.90 * * *$ & $5.71 * * *$ & 2.84 & 3.60 & 3.41 & 3.45 & 3.33 \\
\hline Disclosure_Content2 & $2.99 * * *$ & $2.38 * * *$ & $2.95^{* * *}$ & $2.93 * * *$ & $2.77 * * *$ & 0.60 & 0.85 & 0.67 & 0.69 & 0.70 \\
\hline deferred_tax_presented & $0.95^{* * *}$ & $0.75^{*}$ & $0.87 * * *$ & $0.90 * * *$ & $0.86^{* * *}$ & 0.38 & 0.59 & 0.51 & 0.43 & 0.47 \\
\hline deferred_tax_expl_notes & $1.42 * * *$ & $1.28 * * *$ & $1.29 * * *$ & $1.22 * * *$ & $1.28 * * *$ & 0.17 & 0.22 & 0.23 & 0.22 & 0.21 \\
\hline deferred_tax_pages & $0.94 * * *$ & 0.85 & $0.93^{* *}$ & $0.92 * *$ & $0.90^{* * *}$ & 0.63 & 0.78 & 0.72 & 0.79 & 0.73 \\
\hline deferred_tax_breakdown & $0.77 * * *$ & $0.64 * * *$ & $0.82 * * *$ & $0.76^{* * *}$ & $0.73^{* * *}$ & 0.22 & 0.33 & 0.32 & 0.30 & 0.29 \\
\hline tax_rate_disclosed & $0.65^{* * *}$ & $0.43^{*}$ & $0.58 * * *$ & $0.64 * * *$ & $0.57 * * *$ & 0.17 & 0.29 & 0.07 & 0.20 & 0.19 \\
\hline goodwill_presented & 0.49 & $0.32 * * *$ & 0.40 & $0.31^{* * *}$ & $0.36^{* * *}$ & 0.55 & 0.57 & 0.56 & 0.64 & 0.59 \\
\hline goodwill_expl_notes & 0.78 & 0.82 & 0.87 & 0.84 & 0.83 & 0.69 & 0.80 & 0.95 & 0.90 & 0.83 \\
\hline goodwill_expl_pages & $0.83 * * *$ & $1.17 * * *$ & $0.82 * * *$ & $1.21 * * *$ & $1.08^{* * *}$ & 0.25 & 0.23 & 0.27 & 0.26 & 0.25 \\
\hline Observations & 78 & 130 & 55 & 153 & 416 & 102 & 96 & 82 & 130 & 410 \\
\hline
\end{tabular}

Notes: This table presents descriptive statistics on the variables used in the disclosure analyses. Website = dummy variable taking the value one if the annual report of the firm was published on its website, and zero otherwise; Bundesanzeiger = dummy variable taking the value one if the annual report of the firm was retrieved through the Elektronischer Bundesanzeiger, and zero otherwise; AR Pages = number of pages of the annual report; MD\&A Pages = number of pages of the Management Discussion and Analysis section of the annual report; Notes Pages $=$ the number of pages of the notes to the financial statement; Disclosure content $1=$ deferred tax presented + abv_deftax_pages $(=1$ if deferred_tax_pages $>$ sample median $)+$ deferred_tax_expl_notes + deferred_tax_breakdown + tax_rate_disclosed + goodwill_presented + goodwill_expl_notes + abv_gw_pages $(=1$ if goodwill_expl_pages > sample median); Disclosure_content $2=$ abv_deftax_pages + deferred_tax_breakdown + tax rate disclosed + abv gw pages, Disclosure content 2 is calculated only for firm-observations that include both deferred tax and goodwill information in the notes (i.e., deferred tax expl_notes $=1$ and goodwill_expl_notes $==1$ ); deferred tax disc $=$ dummy variable taking the value one if deferred taxes are presented on the balance sheet, and zero otherwise. deferred_tax_pages = number of pages related to information on deferred taxes disclosed in the notes; deferred_tax_expl_notes = dummy variable that 
takes the value of one if the notes contain explanatory information on deferred taxes, and zero otherwise; deferred_tax_breakdown $=$ dummy variable that takes the value of one if the firm shows a breakdown into deferred tax assets and liabilities, and zero otherwise; tax rate disclosed = dummy variable that takes the value of one if the tax rate applicable to the company is disclosed; goodwill_presented = dummy variable that takes the value of one if goodwill is separately presented on the balance sheet, and zero otherwise; goodwill_expl_notes = dummy variable that takes the value of one if the notes contain explanatory information related to goodwill; goodwill_expl_pages = number of pages related to information on goodwill disclosed in the notes. 


\section{TABLE 7}

Comparison of Disclosure Practices of Private IFRS and German GAAP Firms in the Postadoption Period

Panel A: IFRS versus German GAAP firms in the Post-adoption period

\begin{tabular}{|c|c|c|c|c|c|}
\hline & $\begin{array}{c}(1) \\
\text { AR Pages }\end{array}$ & $\begin{array}{c}\text { (2) } \\
\text { MD\&A Pages }\end{array}$ & $\begin{array}{c}(3) \\
\text { Notes Pages }\end{array}$ & $\begin{array}{c}\text { (4) } \\
\text { Disclosure Content1 }\end{array}$ & $\begin{array}{c}\text { (5) } \\
\text { Disclosure Content2 }\end{array}$ \\
\hline IFRS & $\begin{array}{c}22.5^{* * * *} \\
(6.2)\end{array}$ & $\begin{array}{l}1.59 \\
(1.2)\end{array}$ & $\begin{array}{c}22.2^{* * * *} \\
(10.5)\end{array}$ & $\begin{array}{c}2.33 * * * \\
(10.0)\end{array}$ & $\begin{array}{c}2.24 * * * \\
(13.6)\end{array}$ \\
\hline Website & $\begin{array}{c}62.9 * * * \\
(12.5)\end{array}$ & $\begin{array}{c}12.5^{* * * *} \\
(7.7)\end{array}$ & $\begin{array}{c}9.14 * * * \\
(4.1)\end{array}$ & $\begin{array}{c}-1.03 * * * \\
(-4.4)\end{array}$ & $\begin{array}{l}-0.10 \\
(-0.8)\end{array}$ \\
\hline Size & $\begin{array}{c}7.72^{* * * *} \\
(6.0)\end{array}$ & $\begin{array}{c}1.97 * * * \\
(3.8)\end{array}$ & $\begin{array}{c}3.43 * * * \\
(5.8)\end{array}$ & $\begin{array}{c}0.29 * * * \\
(4.3)\end{array}$ & $\begin{array}{c}0.082^{*} \\
(1.8)\end{array}$ \\
\hline Capital intensity & $\begin{array}{l}-2.34 \\
(-0.2)\end{array}$ & $\begin{array}{r}1.54 \\
(0.3)\end{array}$ & $\begin{array}{l}-5.47 \\
(-1.1)\end{array}$ & $\begin{array}{c}-1.98 * * * \\
(-3.6)\end{array}$ & $\begin{array}{l}-0.080 \\
(-0.2)\end{array}$ \\
\hline Sales growth & $\begin{array}{l}-1.83 \\
(-1.1)\end{array}$ & $\begin{array}{l}-0.53 \\
(-0.8)\end{array}$ & $\begin{array}{c}-2.82^{* * * *} \\
(-2.8)\end{array}$ & $\begin{array}{l}0.15 \\
(1.0)\end{array}$ & $\begin{array}{c}0.041 \\
(0.4)\end{array}$ \\
\hline Leverage & $\begin{array}{l}5.97 \\
(0.8)\end{array}$ & $\begin{array}{l}-0.61 \\
(-0.2)\end{array}$ & $\begin{array}{l}3.43 \\
(0.8)\end{array}$ & $\begin{array}{l}-0.30 \\
(-0.6)\end{array}$ & $\begin{array}{l}0.13 \\
(0.4)\end{array}$ \\
\hline ROA & $\begin{array}{l}-1.61 \\
(-0.1)\end{array}$ & $\begin{array}{l}3.32 \\
(0.6)\end{array}$ & $\begin{array}{l}-4.69 \\
(-0.6)\end{array}$ & $\begin{array}{l}-1.09 \\
(-0.9)\end{array}$ & $\begin{array}{l}-1.28 \\
(-1.6)\end{array}$ \\
\hline Big5 & $\begin{array}{l}-1.85 \\
(-0.7)\end{array}$ & $\begin{array}{l}-0.31 \\
(-0.3)\end{array}$ & $\begin{array}{l}0.78 \\
(0.5)\end{array}$ & $\begin{array}{c}0.070 \\
(0.3)\end{array}$ & $\begin{array}{l}0.010 \\
(0.07)\end{array}$ \\
\hline Foreign Sales & $\begin{array}{l}-0.042 \\
(-0.7)\end{array}$ & $\begin{array}{c}0.0064 \\
(0.3)\end{array}$ & $\begin{array}{c}-0.061^{*} \\
(-1.8)\end{array}$ & $\begin{array}{c}0.0044 \\
(1.3)\end{array}$ & $\begin{array}{c}0.0021 \\
(1.0)\end{array}$ \\
\hline Stock Corporation & $\begin{array}{l}5.81 \\
(1.4)\end{array}$ & $\begin{array}{l}0.056 \\
(0.03)\end{array}$ & $\begin{array}{l}3.67 * \\
(1.9)\end{array}$ & $\begin{array}{l}0.26 \\
(1.2)\end{array}$ & $\begin{array}{c}0.35^{* *} \\
(2.5)\end{array}$ \\
\hline IPO & $\begin{array}{l}12.6^{*} \\
(1.7)\end{array}$ & $\begin{array}{c}8.55^{* * * *} \\
(2.8)\end{array}$ & $\begin{array}{l}1.77 \\
(0.5)\end{array}$ & $\begin{array}{l}0.25 \\
(0.8)\end{array}$ & $\begin{array}{l}-0.17 \\
(-1.0)\end{array}$ \\
\hline Rating & $\begin{array}{l}9.46 \\
(1.6)\end{array}$ & $\begin{array}{l}4.90 \\
(1.5)\end{array}$ & $\begin{array}{l}-2.42 \\
(-0.7)\end{array}$ & $\begin{array}{l}0.21 \\
(0.4)\end{array}$ & $\begin{array}{l}0.28 \\
(1.2)\end{array}$ \\
\hline Bonds & $\begin{array}{c}0.23 \\
(0.04)\end{array}$ & $\begin{array}{l}-1.99 \\
(-0.6)\end{array}$ & $\begin{array}{l}0.53 \\
(0.2)\end{array}$ & $\begin{array}{l}-0.57 \\
(-1.4)\end{array}$ & $\begin{array}{l}-0.35 \\
(-1.5)\end{array}$ \\
\hline Profit Participation Certificates & $\begin{array}{l}-7.91 \\
(-0.8)\end{array}$ & $\begin{array}{l}-3.67 \\
(-0.8)\end{array}$ & $\begin{array}{l}-2.72 \\
(-0.8)\end{array}$ & $\begin{array}{l}0.38 \\
(0.7)\end{array}$ & $\begin{array}{c}-0.0055 \\
(-0.02)\end{array}$ \\
\hline PE Ownership & $\begin{array}{l}-4.87 \\
(-1.0)\end{array}$ & $\begin{array}{l}-0.90 \\
(-0.4)\end{array}$ & $\begin{array}{l}0.22 \\
(0.1)\end{array}$ & $\begin{array}{l}0.22 \\
(0.8)\end{array}$ & $\begin{array}{c}0.071 \\
(0.5)\end{array}$ \\
\hline Constant & $\begin{array}{c}-160.9 * * * \\
(-5.1)\end{array}$ & $\begin{array}{c}-45.3 * * * \\
(-3.4)\end{array}$ & $\begin{array}{c}-66.2 * * * \\
(-5.0)\end{array}$ & $\begin{array}{l}-2.05 \\
(-1.6)\end{array}$ & $\begin{array}{c}-2.61 * * \\
(-2.5)\end{array}$ \\
\hline $\begin{array}{l}\text { Industry dummies } \\
\text { Year dummies }\end{array}$ & $\begin{array}{l}\text { Included } \\
\text { Included }\end{array}$ & $\begin{array}{l}\text { Included } \\
\text { Included }\end{array}$ & $\begin{array}{l}\text { Included } \\
\text { Included }\end{array}$ & $\begin{array}{l}\text { Included } \\
\text { Included }\end{array}$ & $\begin{array}{l}\text { Included } \\
\text { Included }\end{array}$ \\
\hline Observations & 711 & 709 & 711 & 711 & 527 \\
\hline IFRS Post-adoption Observations & 362 & 362 & 362 & 362 & 302 \\
\hline R-squared & 0.79 & 0.59 & 0.61 & 0.50 & 0.67 \\
\hline Adjusted R-squared & 0.78 & 0.57 & 0.59 & 0.48 & 0.65 \\
\hline
\end{tabular}


TABLE 7 (continued)

Panel B: IFRS versus German GAAP firms in the Post-adoption period by cluster

\begin{tabular}{lccccc}
\hline & $(1)$ & $(2)$ & $(3)$ & $(4)$ & $(5)$ \\
& AR Pages & MD\&A Pages & Notes Pages & Disclosure Content1 & Disclosure Content2 \\
\hline EQUITY & $22.5^{* *}$ & -0.52 & $22.5^{* * *}$ & $4.32^{* * *}$ & $3.32^{* * *}$ \\
& $(2.5)$ & $(-0.1)$ & $(5.4)$ & $(4.5)$ & $(6.4)$ \\
DEBT & & & & $2.04 * * *$ \\
& $30.1^{* * *}$ & $5.39^{*}$ & $24.2^{* * *}$ & $\left(2.51^{* *}\right.$ & $(3.3)$ \\
FINCON-PE & $(3.6)$ & $(1.8)$ & $(5.3)$ & & $2.28^{* * *}$ \\
& $25.1^{* * *}$ & $4.28^{* *}$ & $25.7^{* * *}$ & $2.74^{* * *}$ & $(6.2)$ \\
REPUTATION & $(4.4)$ & $(2.3)$ & $(7.7)$ & $(5.5)$ & $1.84^{* * *}$ \\
& $21.0^{* * *}$ & -0.066 & $19.5^{* * *}$ & $(4.5)$ & $(7.3)$ \\
\hline
\end{tabular}

Notes: This table presents results of regressions of disclosure variables on a dummy variable, IFRS, capturing the difference in disclosure practices of IFRS and German GAAP reporting firms, and control variables in the postadoption period (differences-in-differences test). Panel A includes all IFRS firms and matched German GAAP firms with available data. Panel B compares IFRS and German GAAP firms by incentive clusters. Website is defined in Table 6. Capital intensity = net property plant and equipment divided by total assets; all other variables are defined in Table 2. Standard errors are clustered at the firm level. *, **, *** indicates significantly different from zero at the $10 \%, 5 \%$, or $1 \%$ level (two-sided). 
TABLE 8

\section{Comparison of Disclosure Practices of Private IFRS and German GAAP Firms}

in the Pre- versus Post-adoption Period (Differences-in-Differences)

\begin{tabular}{|c|c|c|c|c|c|}
\hline & $\begin{array}{c}(1) \\
\text { AR Pages } \\
\end{array}$ & $\begin{array}{c}(2) \\
\text { MD\&A Pages }\end{array}$ & $\begin{array}{c}\text { (3) } \\
\text { Notes Pages } \\
\end{array}$ & $\begin{array}{c}(4) \\
\text { Disclosure Content1 } \\
\end{array}$ & $\begin{array}{c}\text { (5) } \\
\text { Disclosure Content2 } \\
\end{array}$ \\
\hline Post & $\begin{array}{l}9.19 \\
(1.6)\end{array}$ & $\begin{array}{l}1.29 \\
(0.8)\end{array}$ & $\begin{array}{l}-1.75 \\
(-0.7)\end{array}$ & $\begin{array}{l}0.65 \\
(1.4)\end{array}$ & $\begin{array}{l}0.15 \\
(0.3)\end{array}$ \\
\hline IFRS & $\begin{array}{l}-3.74 \\
(-0.4)\end{array}$ & $\begin{array}{l}-1.76 \\
(-0.5)\end{array}$ & $\begin{array}{l}-3.59 \\
(-1.2)\end{array}$ & $\begin{array}{l}-0.031 \\
(-0.05)\end{array}$ & $\begin{array}{l}0.11 \\
(0.2)\end{array}$ \\
\hline IFRS*Post & $\begin{array}{l}19.2^{* * * *} \\
(2.9)\end{array}$ & $\begin{array}{l}1.87 \\
(0.7)\end{array}$ & $\begin{array}{l}20.7 * * * * \\
(4.2)\end{array}$ & $\begin{array}{l}1.85^{* *} \\
(2.5)\end{array}$ & $\begin{array}{l}1.80^{* * * *} \\
(3.5)\end{array}$ \\
\hline Website & $\begin{array}{c}35.8^{* * * *} \\
(2.8)\end{array}$ & $\begin{array}{l}3.17 \\
(0.9)\end{array}$ & $\begin{array}{l}1.72 \\
(0.4)\end{array}$ & $\begin{array}{l}-1.14^{*} \\
(-1.8)\end{array}$ & $\begin{array}{l}-0.13 \\
(-0.5)\end{array}$ \\
\hline Size & $\begin{array}{c}9.27 * * \\
(2.4)\end{array}$ & $\begin{array}{l}1.53 \\
(1.1)\end{array}$ & $\begin{array}{l}2.14 \\
(1.4)\end{array}$ & $\begin{array}{c}0.42 * * \\
(2.1)\end{array}$ & $\begin{array}{l}0.17 \\
(1.4)\end{array}$ \\
\hline Capital intensity & $\begin{array}{l}24.0 \\
(0.9)\end{array}$ & $\begin{array}{l}16.4^{*} \\
(2.0)\end{array}$ & $\begin{array}{l}-0.51 \\
(-0.07)\end{array}$ & $\begin{array}{l}-0.50 \\
(-0.4)\end{array}$ & $\begin{array}{l}-1.85^{* *} \\
(-2.1)\end{array}$ \\
\hline Sales growth & $\begin{array}{l}-7.28 \\
(-1.0)\end{array}$ & $\begin{array}{l}0.34 \\
(0.2)\end{array}$ & $\begin{array}{c}-8.14 * * \\
(-2.7)\end{array}$ & $\begin{array}{l}-0.64 \\
(-1.4)\end{array}$ & $\begin{array}{l}-0.082 \\
(-0.2)\end{array}$ \\
\hline Leverage & $\begin{array}{l}58.1^{*} \\
(1.9)\end{array}$ & $\begin{array}{l}12.3 \\
(1.4)\end{array}$ & $\begin{array}{l}7.56 \\
(0.9)\end{array}$ & $\begin{array}{l}2.09 \\
(1.3)\end{array}$ & $\begin{array}{l}-0.75 \\
(-0.6)\end{array}$ \\
\hline ROA & $\begin{array}{l}8.27 \\
(0.2)\end{array}$ & $\begin{array}{l}17.5 \\
(1.0)\end{array}$ & $\begin{array}{l}-8.44 \\
(-0.6)\end{array}$ & $\begin{array}{l}2.71 \\
(0.7)\end{array}$ & $\begin{array}{c}0.029 \\
(0.008)\end{array}$ \\
\hline Big5 & $\begin{array}{l}-1.72 \\
(-0.3)\end{array}$ & $\begin{array}{l}1.33 \\
(0.6)\end{array}$ & $\begin{array}{l}4.57 \\
(1.7)\end{array}$ & $\begin{array}{l}0.083 \\
(0.2)\end{array}$ & $\begin{array}{l}-0.21 \\
(-0.6)\end{array}$ \\
\hline Foreign Sales & $\begin{array}{l}0.12 \\
(1.0)\end{array}$ & $\begin{array}{l}0.030 \\
(0.7)\end{array}$ & $\begin{array}{l}-0.013 \\
(-0.3)\end{array}$ & $\begin{array}{c}-0.0023 \\
(-0.3)\end{array}$ & $\begin{array}{c}-0.0025 \\
(-0.4)\end{array}$ \\
\hline Stock Corporation & $\begin{array}{l}4.28 \\
(0.6)\end{array}$ & $\begin{array}{l}-2.98 \\
(-1.1)\end{array}$ & $\begin{array}{l}1.50 \\
(0.6)\end{array}$ & $\begin{array}{l}-0.72^{*} \\
(-2.0)\end{array}$ & $\begin{array}{l}0.079 \\
(0.2)\end{array}$ \\
\hline IPO & $\begin{array}{l}40.5^{* *} \\
(2.4)\end{array}$ & $\begin{array}{c}23.4 * * * \\
(3.5)\end{array}$ & $\begin{array}{l}11.0^{* * *} \\
(2.2)\end{array}$ & $\begin{array}{l}0.54 \\
(0.7)\end{array}$ & $\begin{array}{l}0.48 \\
(0.8)\end{array}$ \\
\hline Rating & $\begin{array}{l}16.0^{*} \\
(1.8)\end{array}$ & $\begin{array}{c}29.3 * * * \\
(4.6)\end{array}$ & $\begin{array}{l}6.71 \\
(1.3)\end{array}$ & $\begin{array}{l}-0.87 \\
(-0.9)\end{array}$ & $\begin{array}{l}0.80 \\
(1.2)\end{array}$ \\
\hline Bonds & $\begin{array}{l}5.29 \\
(0.3)\end{array}$ & $\begin{array}{c}-20.5^{* *} \\
(-2.4)\end{array}$ & $\begin{array}{l}-0.86 \\
(-0.1)\end{array}$ & $\begin{array}{l}0.96 \\
(0.8)\end{array}$ & $\begin{array}{l}-0.59 \\
(-0.9)\end{array}$ \\
\hline Profit Participation Certificates & $\begin{array}{l}-0.56 \\
(-0.03)\end{array}$ & $\begin{array}{c}28.8^{* *} \\
(2.6)\end{array}$ & $\begin{array}{l}3.64 \\
(0.5)\end{array}$ & $\begin{array}{l}-0.056 \\
(-0.04)\end{array}$ & $\begin{array}{l}0.80 \\
(0.9)\end{array}$ \\
\hline PE Ownership & $\begin{array}{l}-8.58 \\
(-0.7)\end{array}$ & $\begin{array}{l}-2.89 \\
(-0.7)\end{array}$ & $\begin{array}{c}6.67 * * \\
(2.4)\end{array}$ & $\begin{array}{l}0.084 \\
(0.2)\end{array}$ & $\begin{array}{l}-0.34 \\
(-1.0)\end{array}$ \\
\hline Constant & $\begin{array}{c}-242.8^{* * *} \\
(-2.7)\end{array}$ & $\begin{array}{l}-41.3 \\
(-1.3)\end{array}$ & $\begin{array}{l}-45.9 \\
(-1.6)\end{array}$ & $\begin{array}{c}-7.49 * * \\
(-2.0)\end{array}$ & $\begin{array}{c}-6.73 * * * \\
(-2.7)\end{array}$ \\
\hline Industry dummies & Included & Included & Included & Included & Included \\
\hline Year dummies & Included & Included & Included & Included & Included \\
\hline Observations & 178 & 178 & 178 & 178 & 122 \\
\hline IFRS Pre-/Post-adoption Observations & $54 / 54$ & $54 / 54$ & $54 / 54$ & $54 / 54$ & $32 / 47$ \\
\hline R-squared & 0.83 & 0.79 & 0.73 & 0.49 & 0.74 \\
\hline Adjusted R-squared & 0.79 & 0.74 & 0.67 & 0.37 & 0.64 \\
\hline
\end{tabular}

Notes: This table compares pre- and post-adoption disclosure practices of IFRS firms, for which we have both preand post-adoption observations, with that of German GAAP firms (differences-in-differences test). Panel A includes all IFRS and German GAAP firms with available data. Website is defined in Table 6. Capital intensity = net property plant and equipment divided by total assets; all other variables are defined in Table 2. Standard errors are clustered at the firm level. *,**,*** indicates significantly different from zero at the $10 \%, 5 \%$, or $1 \%$ level (two-sided). 
TABLE 9

Disclosure Channel of Private Firms' Financial Statements in the Post-adoption Period

\begin{tabular}{|c|c|c|c|c|c|}
\hline & (1) & (2) & (3) & (4) & $(5)$ \\
\hline Dependent variable: Website & All IFRS & EQUITY & DEBT & FINCON-PE & REPUTATION \\
\hline IFRS & $\begin{array}{c}0.47^{*} \\
(1.8)\end{array}$ & $\begin{array}{c}6.71 * * * \\
(6.0)\end{array}$ & $\begin{array}{c}1.24 * * * \\
(2.8)\end{array}$ & $\begin{array}{c}1.42 * * \\
(2.5)\end{array}$ & $\begin{array}{c}1.33 * * * \\
(2.9)\end{array}$ \\
\hline Size & $\begin{array}{c}0.40^{* * * *} \\
(5.6)\end{array}$ & $\begin{array}{c}0.54 * * * \\
(2.7)\end{array}$ & $\begin{array}{c}1.01 * * * \\
(5.5)\end{array}$ & $\begin{array}{c}0.90 * * * \\
(3.4)\end{array}$ & $\begin{array}{c}0.45 * * * \\
(2.7)\end{array}$ \\
\hline Capital intensity & $\begin{array}{l}-0.20 \\
(-0.4)\end{array}$ & $\begin{array}{l}-0.92 \\
(-0.7)\end{array}$ & $\begin{array}{l}-1.30 \\
(-0.8)\end{array}$ & $\begin{array}{l}0.75 \\
(0.6)\end{array}$ & $\begin{array}{l}1.75 \\
(1.6)\end{array}$ \\
\hline Sales growth & $\begin{array}{c}-0.39 * * \\
(-2.0)\end{array}$ & $\begin{array}{c}-1.61 * * * \\
(-3.8)\end{array}$ & $\begin{array}{l}-0.92 \\
(-1.6)\end{array}$ & $\begin{array}{l}-0.29 * \\
(-1.8)\end{array}$ & $\begin{array}{l}0.84 \\
(0.7)\end{array}$ \\
\hline Leverage & $\begin{array}{l}-0.64 \\
(-1.3)\end{array}$ & $\begin{array}{l}-1.50 \\
(-1.3)\end{array}$ & $\begin{array}{l}-1.96 \\
(-1.4)\end{array}$ & $\begin{array}{l}-1.13 \\
(-0.9)\end{array}$ & $\begin{array}{l}0.44 \\
(0.3)\end{array}$ \\
\hline ROA & $\begin{array}{l}1.99 * \\
(1.7)\end{array}$ & $\begin{array}{c}5.13^{* *} \\
(2.5)\end{array}$ & $\begin{array}{l}2.27 \\
(0.7)\end{array}$ & $\begin{array}{c}7.14^{* * *} \\
(2.1)\end{array}$ & $\begin{array}{l}1.63 \\
(0.4)\end{array}$ \\
\hline Big5 & $\begin{array}{l}-0.21 \\
(-1.0)\end{array}$ & $\begin{array}{l}-0.41 \\
(-0.9)\end{array}$ & $\begin{array}{l}-0.25 \\
(-0.4)\end{array}$ & $\begin{array}{l}-0.47 \\
(-0.7)\end{array}$ & $\begin{array}{l}0.41 \\
(0.9)\end{array}$ \\
\hline Foreign Sales & $\begin{array}{c}-0.0017 \\
(-0.5)\end{array}$ & $\begin{array}{c}-0.029 * * * \\
(-2.9)\end{array}$ & $\begin{array}{c}0.0016 \\
(0.2)\end{array}$ & $\begin{array}{c}-0.0066 \\
(-0.8)\end{array}$ & $\begin{array}{c}0.0038 \\
(0.5)\end{array}$ \\
\hline Stock Corporation & $\begin{array}{c}0.57 * * \\
(2.6)\end{array}$ & $\begin{array}{l}0.56 \\
(0.9)\end{array}$ & $\begin{array}{c}0.079 \\
(0.2)\end{array}$ & $\begin{array}{l}0.48 \\
(0.8)\end{array}$ & $\begin{array}{c}1.64 * * * \\
(4.0)\end{array}$ \\
\hline IPO & $\begin{array}{c}1.30 * * * \\
(3.7)\end{array}$ & & $\begin{array}{c}3.48 * * \\
(2.2)\end{array}$ & $\begin{array}{c}-1.95 * * \\
(-2.2)\end{array}$ & $\begin{array}{l}-0.46 \\
(-1.0)\end{array}$ \\
\hline Rating & $\begin{array}{l}0.27 \\
(0.6)\end{array}$ & & & & \\
\hline Bonds & $\begin{array}{c}0.85^{* * *} \\
(2.2)\end{array}$ & $\begin{array}{c}-2.78 * * * \\
(-2.7)\end{array}$ & & & \\
\hline Profit Participation Certificates & $\begin{array}{l}-1.04 \\
(-1.3)\end{array}$ & & $\begin{array}{l}2.44 * \\
(1.8)\end{array}$ & & \\
\hline PE Ownership & $\begin{array}{c}-0.59 * \\
(-1.8)\end{array}$ & $\begin{array}{c}-3.30 * * * \\
(-4.8)\end{array}$ & $\begin{array}{l}-1.84 \\
(-1.6)\end{array}$ & & \\
\hline Constant & $\begin{array}{c}-7.63 * * * \\
(-4.4)\end{array}$ & $\begin{array}{c}-7.79 * * \\
(-2.1)\end{array}$ & $\begin{array}{c}-19.5^{* * *} \\
(-5.0)\end{array}$ & $\begin{array}{c}-18.6^{* * * *} \\
(-3.6)\end{array}$ & $\begin{array}{c}-13.0 * * * \\
(-3.6)\end{array}$ \\
\hline $\begin{array}{l}\text { Industry dummies } \\
\text { Year dummies }\end{array}$ & $\begin{array}{l}\text { Included } \\
\text { Included }\end{array}$ & $\begin{array}{l}\text { Included } \\
\text { Included }\end{array}$ & $\begin{array}{l}\text { Included } \\
\text { Included }\end{array}$ & $\begin{array}{l}\text { Included } \\
\text { Included }\end{array}$ & $\begin{array}{l}\text { Included } \\
\text { Included }\end{array}$ \\
\hline Observations & 664 & 148 & 161 & 102 & 201 \\
\hline IFRS Observations & 328 & 60 & 84 & 46 & 108 \\
\hline Pseudo R-squared & 0.39 & 0.56 & 0.79 & 0.43 & 0.53 \\
\hline
\end{tabular}

Notes: This table presents results of probit regressions of private firms' choice of disclosure channel for their financial reports. The dependent variable is Website and defined in Table 6. Capital intensity $=$ net property plant and equipment divided by total assets; all other variables are defined in Table 2. Standard errors are clustered at the firm level. *, **, *** indicates significantly different from zero at the $10 \%, 5 \%$, or $1 \%$ level (two-sided). 